\title{
Development of our Modern War Fleet
}

\author{
J. Scott Russell Esq., F.R.S., \&c., \&c.
}

To cite this article: J. Scott Russell Esq., F.R.S., \&C., \&c. (1877) Development of our Modern War Fleet, Royal United Services Institution. Journal, 21:91, 708-753, DOI: $\underline{10.1080 / 03071847709415813}$

To link to this article: http://dx.doi.org/10.1080/03071847709415813

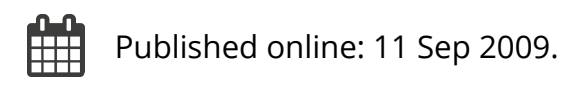

Submit your article to this journal

Џ Article views: 4

Q View related articles $\sqsubset$ 


\title{
LECTIJRE.
}

\author{
Friday, June 8th, 1877.

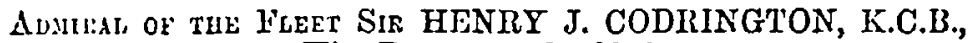 \\ Pice-Patron, in the Chair.
}

\section{DEVLLOPMENT OF OUR MIODERN WAR FLELT.}

By J. Scorr Rossele, Lsq., F.R.S., dc., \&c.

I DEEy it a high honour that the duty has been assigued to mo of laying before this inceting a summary of the new conditions which have arisen in Modern Naral Warfare, and of submitting to you tho means we may be able to put into practical use for ensuring English naral supremacy over the oceans of the empire.

I highly npprecinto this occasion, becauso I sce in this Institution the most distinguished and the most experienced members of tho tro noble professions on whom we must always rely for the maintenanco of the fredom, power, and rell-being of the Fnglish nation; for with reference to war I believe no maxim more decply truo than that "Readiness for war means power to keep tho peace," and there is one other less known bot not less true that-

"Diplomacy makes wars-The army and nary cnd them."

$\Lambda$ s thero are present members of both services who bave fought battles in our past wars, and who will haro to tako a leading part in our coming wars, I desire to put myself, as far as I may be allowed, in the position of asking sou for professional adrice and information. I take my own position simply as an elder brother of another profes. sion; and the duty of my profession is not to give you information on matters of rar, but to ask jou for information to enable my profession to do our duty by yours. Our duty then I take to bo this-

"To preparo for your use-'The fittest tools for your work."

Therefore I want to learn from you-

"What your work is to be-And how you wish to set abont it."

Any information I possess as to the present wants of the naval service and the future fighting of the British fleet, I owe to the long and intimate knowledge $I$ have enjoyed of the riews and experiences of distinguished naval and artillery officers, and of men in command of war ships and fleets, not only in our own bat in other services. In the Grimean War I am happy to say vessels of my design and construction, ably commanded and ably handled, did good servico to our 
country, and carned merited distinction for their Officers; and the Oflicers of successful smaller vessels of those days vill, I hatre no doubt, successfully command our flects of large slips in the coming war. It is the knowledgo of our ablest naval commanders which I aim at possessing; if I cver made a good ship, it was by studying the wants of an able commander, and I have done my best to learn your present wants, and to consider and contrire the fittest means for the exccution of your intentions. Ono defect in my address to this mecting I mast apologise to you for. One of the objects of our "further development of our flects" must bo the criticism, correction, and remedy of the crrors of the past and the present. Now if this paper had been read in other political circumstances, I might hare nndertaken the unpleasant duty of exposing the faults and blunders of our present ships of war. But at the present time that would not be prudent, useful, nor patriotic. Theso faults are well known to you and to me. But this is not a fit timo to dwell on them. I will there. foro omit this large, urgent, and interesting part of the question, and confine mysclf to the consideration of tho naturo of such new work as we shall soon liave to undertake and to carry out.

About our cxisting ships of war I havo only this to say, that according to my experienco as ship builder, ship owner, and scaman, I have always found that a good captain makes a good ship, and an incompetent captain makes a helpless ship, and I tirmly belicro that our naval commanders will take what is called a bad ship to sca, and by mastering all her qualities, good and bad, by gaining the complete contidence of all on board, and by the exerciso of forethought, foresight, coolness and courage, will make the best of such ship, engines and guns as they hare got, and that what are called bad ships, mas in good lands, win the victory.

In this paper I shall direct my attention solely to the determination of tho objects we should mainly beep in view in the futuro derelopment of the flects of the empire, including in " empirc," the shores of our colonics, tho dominions of the British empire, and the ocenns covored by onr commerce.

The first question I havo askel of your profession is this:-

What is a modern sea fight?

How do you nean to set about it?

The answers I havo received havo becn mauy aud rarions. But in the end, I think I understand what you man to do. I think I sco tho like means to cuablo you to do it.

\section{I.}

\section{A Modern Sca Fight.}

Judging from all the information I have gathered from able and cxperienced comnanders of flects and ships, I think the following epitome illustrates their views and intentions; and, in order to master tho subject and meet its difliculties, I have tried for the moment to pat myself in the commander's place, and tricel to understand his motives, means, and action, and thence I havo tripld to contrive and invent tho means that would best fulfil his aims and achicre his end. 
According to all tho information I haro gathered from the ablest men, the following series of facts aro to bo dealt witl.

\section{The Fight Begins.}

Standing on the deck, 24 feet above the watcr,' I sco my cnemy clear on the horizon. Ho is secking me. I nm seeking him. We are six miles apart; at modest speed a mile takes six minutes; at that speed wo shall meet in cighteen minutes.

What to do in these cightecn minutes is a serious question.

There is not a heavy sea on but an ordinary swell, our ships roll gently; steam stendily; our guns are eluarged; all is ready.

Now comes the scrious question $-A$ s we approach shall we fire o: not?

\section{Trelve Minutcs.}

Six minutes have passed, and we are now within four uniles of eacle other, shall we throw array our shot?

\section{Six Minutes.}

Sir minutes moro haro passcd, wo are within 1,000 yards of cacls other, shall we throw away our shot?

Better rescrve all for near and suro firo.

Threo Minutes.

Wo are now end on. 2,000 yards apart. Thuree minutes of time left. Shall we continue end on?

Shall we change our courso?

Why chango our course?

I clare not chango my courso!

'That is the answer to mo hy an ablo aud cxperienced conmanler.

Now I quite agree with our brare scaman that le dare not change his course. It would be wenleness. It would be ferr. It might be folly.

His orders must he Stand by ! Stcaly ! Full specd ahead!

\section{Three Minutes apurt.}

The three minutes are soon over! The engineer grets all in order for the erash ! $A l l$ in the ship is alrealy made fast! The commatnder's eje never leares the enemy. $\Lambda t$ tho end of a minute, ho secs the enemy liesitate.

Ife swerres to port! Port the helm is our order. The ship swerves to port, but is too slow to escapo us.

The two minutes are orer, ho has not been ablo to get round more than four points. We also have got four points round, we are now fnll speed right athwart his beam.

Stem on. Stem into him. His side is open to the ser.

1 Mr knowing this height exactly, chables me to tell his distance cxnc:ly: 
Second Sluge of Fight.

In this ease we liavo won-and won easily. The weakness of our cnemy was-to stay so long and swerre too late.

Suppose he had decided sooner, and gone about sooner, and been clearer, and we had dono the same, ho might hare escaped collision. What then?-Then in passing him I should have delivered into him my cntire broadsile.

All this would hare passed in twenty minutes from sighting, and in six minutes more we should either be once more broadside on or end on-as wo were. The second meeting end on or broadside, one or both-unless one of us was already disabled-would bo a repetition of the choice between mecting or swerving.

\section{Alteralion. First Stage.}

Let us now go back to our original position-three minutes' apart, end on. 'The enems does not swerve-we do not swerre-we meet fill speed, stem to stem.

$\Lambda$ there is a sen on and the ships gently roll, stem may not meet stem in perfect line, ove of us will stem the other asido more or less. If wo are both strong aud well made, each may strike the other and rehound-damaged and not disabled-each may go on, discharge his broadside guns, and six minutes after wo may be meeting end on or right athwart. Whicherer side may win, it seems unlikely that one engagement betiveen two such ships will last through more than three such encounters, or that the tiune of au engagement will be prolonged. lighteen minutes to inect and eighteen minutes' close quarters seems a long fight.

it scems to me that the lessons I learn from these data are thesethat the first fighting element I hare to meet is "greatest strength to "strike my cnemy with most harm to him and least to me," that the second fighting element is "greatest gun power"-to throw the greatest number of largest shells into him with highest speed at closo dislance and in shortest time. These two are, it seems, the first lighting elements which the moderi man-of-war must possess.

II.

\section{Our Modern Man-of-IWar.}

The first condition of the modern man-of-war is, that she be fit to fight this battle and sure to win it.

To fight and win we must be-

Specdier, so as to choose our own time and place.

Ilandier, so as to choose the best bearings.

Stronger Burcel, so as to sink him without being sunk.

With more Gun Pover, so as to throw more and larger shells with greater initial velocity at close range.

How to get these fighting points without sacrificing any of the essentials of a seawortly, sea-kecping, wholesome ship, leads into questions of practical detail. But before going into the details of our 
future men-oforrar, it is expedient to limit our aims by elenly defining the ends we have in view.

Do we aim at perfect impenetrability of armour-clad ships?

Do we aim at perfect unsinkability of the luulls of onr ships?

Do we aim at perfect security of Offeers and gunners, eugineers and seamen, from risk of life and limb ?

I ask theso rather absurd questions, because we have had nuch talk here perhaps and elsewhere, of things called ships which are to be utterly impregnable and indestructible, impenetrable to shot, shell, firo and water.

In reply, then, I hope I may be allowed to assume that neither you nor $I$, nor any men in power, look forward to, or expect, or will sanction any pretence, of making the ships of the future war-navy perfectly. impregnable; such fancies or pretences would be unworthy of sour countenance and mero waste of time. No doubt a ship may be made to carry armour 1,2,3,5 feet thick; no donbt guns can be made $100,200,300,500$ tons in weight, carrying shot of $1,2,3,5$ tons in weight; no doubt gun makers like to be paid for bailding monster guns; no doubt good blacksmiths like to bo paid for rolling and hammering thick armour plates; no donbt also the talk about such big things may frighten our foes if they are fools, and might give confidence to our friends if they are fools. But I feel that I need not refute such follies in this society, beenase they would not be seriously cntertained here.

I begin, then, by assuming that you don't expect ine to talk of ships quito impenetrable to shot and shell of all kinds, ships quite unsinkable by shot and shell of any size, bottoms so strong as to anchor peaccfully orer a mine for the purpose of being blown up with impunity, guns so large that a single slot will sink a Aect, and an interior so large that provision and fuel can be carricd for any number of battles all round the world.

If you wero to desiro me to indulge sou in foolish fancies of that sort made for your amusement, I should begin at once with the wonderons round ships of which we haro heard so much; I should tell you how if you mado a round ship of 100 fect diameter, you might give her 1,000 tons of armour, 1,000 tons of gans and ammunition, and 1,000 tons of coal ; if jou made her 200 fect dinmeter, she would carry 4,000 tons of armour, 4,000 tons of guns, 4,000 tons of coal; if you went to 300 fect diameter, she would carry 9,000 tons of armonr, 9,000 tons of guns, 9,000 tons of conl; how at 500 feet diameter she would carry 25,000 tons of armour, 25,000 tons of guns and ammunition, 25,000 tons of coal; how all the ships in the rorld might bombard her for twelre months without doing her serious harm, but amasing her and themselves by waste of powder and shot.

All this yon might take in good part if we were in st here mercly for fun. It might also amuso you to know that I really designed such a gigantic round floating fortress twenty ycars ago for real use, bat I never called that a ship, and I hope you will never consider one of such, or any number of them, as a ship or as a fleet.

I undersiand, therefore, that we are not here talking of circulite 
batteries, floating forts, or any of those fancies which fertile imagination may disport in creating; bat we are to consider how we may mako sure progress, in creating sea-going, sea-keeping, speedy, handy ships, on giren conditions of least waste of money, time, and human life, and meant for the parpose of protecting the wide-sprend interests of the English race, the cmpire of the ocean, and the commerce of our large colonial family with the mother country and with the shores of all seas, and for the purpose of denling summarily with the ships of any evemy who may wish to capture our wide-spread fleets of merchantmen and plunder the wealth they carry, or who may be ambitious of attaching to their own empires, some of that large family of English colonics, and of English dominions, which do so much for the wealth, well-bcing, cirilization, liberty, and progress of haman society. 'That family we mast protect at all risks, and it is to the larger question of thas protecting the interests, the honour, and the power of the British Empire, that I hare dirceted my thoughts in preparing to address this meeting of England's protectors.

\section{III.}

\section{Ramming Poucei and Low Struclure.}

Since ramming power takes first rant in the war ship, I hare carefully examined our own ships and other people's with the aim of sceing what kind of rom or stem will do them most harm and sink them soonest.

I find that cutting them open "across the water-line" is tho way and place to do most harm and sink them soonest. The best tool for this purpose is a good upright seagoing stem, having its greatest projection at its own water-line and rounded backwards above and below. This is also a good shapo of stern for a sea-going ship.

I do not find that the sharp point or nnderwater beak often uscd, is a good weapon. It weakens the ship, gives a lerer to the enemy, and makes $a$ small opening instead of a great onc. What is wanted, is a stem which is the strongest and at the same timo opens up the largest part of the enemy in the most'dangerous place. 'To cut open the water-lino above and below, will let in most water in the place to do most harm and soonest sink the ship.

That a nearly upright stem rounded back abore and below the water-line, will do most harm is plain from this circumstance, that it cuts across the decks. A sharp point may penetrate between two decks which are wateriight, and do littlo harm, admitting water only on one deck; but an upright stem cutting across two decks, lets water in to fll three decks, and as the entrance of water licels the ship over, more and more of the opening gets under water and mnch more of the ship is inundated. I should mach prefer my ship being picreed by a sharp point than cut open across my decks.

I nm also of opinion that our stemming structure is reak. A strong heary lump of iron called a stem is rcally a very fecble offensive weapon, becanse it is not so made as to be in one with all the ship behind. Hence we see that the ship which rans, is often more injured 
than the other. I hare seen ships that liave rammed others at sea come back sinking becauso their bows and stems were not so made as to give each other due support.

The stem of a ramming ship should be built up quite differently from past custom. Our large single forgings, stopping short in thin iron sheets, are sinply useless dead weight, and nu oblique collision with an iron-plated ship will simply double the bow round, if not tear it open.

What wo want in collision-construction is that the strong thick parts of the ship should grow evenly out of the weaker thinner parts abaft, so that the strain of collision shall bo spread orer a wide space, and so utilizing the strength of a large extent of good iron. For this purpose the stem must be formed by gradually growing out of the ship's bows in plates overlapping thicker and thicker until they become a thick, smooth inflexible stem, quite different from common patchwork.

The same principle must prevail throughout the whole bow of a ship. The decks must all be incorpornted in the interior of the liull with the shin and the stem, so as to form one entire hollow weapon of great strength and homogencous structure, without the present points of weakness. This, though practicable, requires mach skill in order to get most work without weakness and without waste.

135 stem and bow strength, I mean not merely on and under water, but up to the summit of the bow. The ship nust be too strong for her enems, not at one place, but all round the how:

\section{IV.}

\section{Precaution and Prolcction ly Casemates.}

Although I adhere to the war maxim, that sinking jour enemy means saving you, I do not therefore feel myself thereby discharged from any of the responsibilities of my daty to do all that in me lies to save your life, and so aid you in your duty by first doing mine. But I beg to say that my iden of my duty and yours is; that barming the enemy is your first duty and mine, that saving ourselves is the second duty, and that we must not sacrifice the first to the second.

Our first duty being to shell our enems and to sink him, I must ask you to agree with me in first giving our ship more sea.worthy qualities, more endurance, more speed, more handiness, more sinking power, and more skelling power than our enems.

Saving power for ourselres, I should give as follows. I should give up all long clear level decks under water, and take exclusively to what I will renture to call-

\section{The System of Casemales.}

The casemate system is that in which we take some convenient unit of bulk, having some practical use as its aim and measure. For this end I take one broadside gan as my unit for bulk. That gun wants room to work it. That room mas be 12 feet wide by 18 feet, call it 


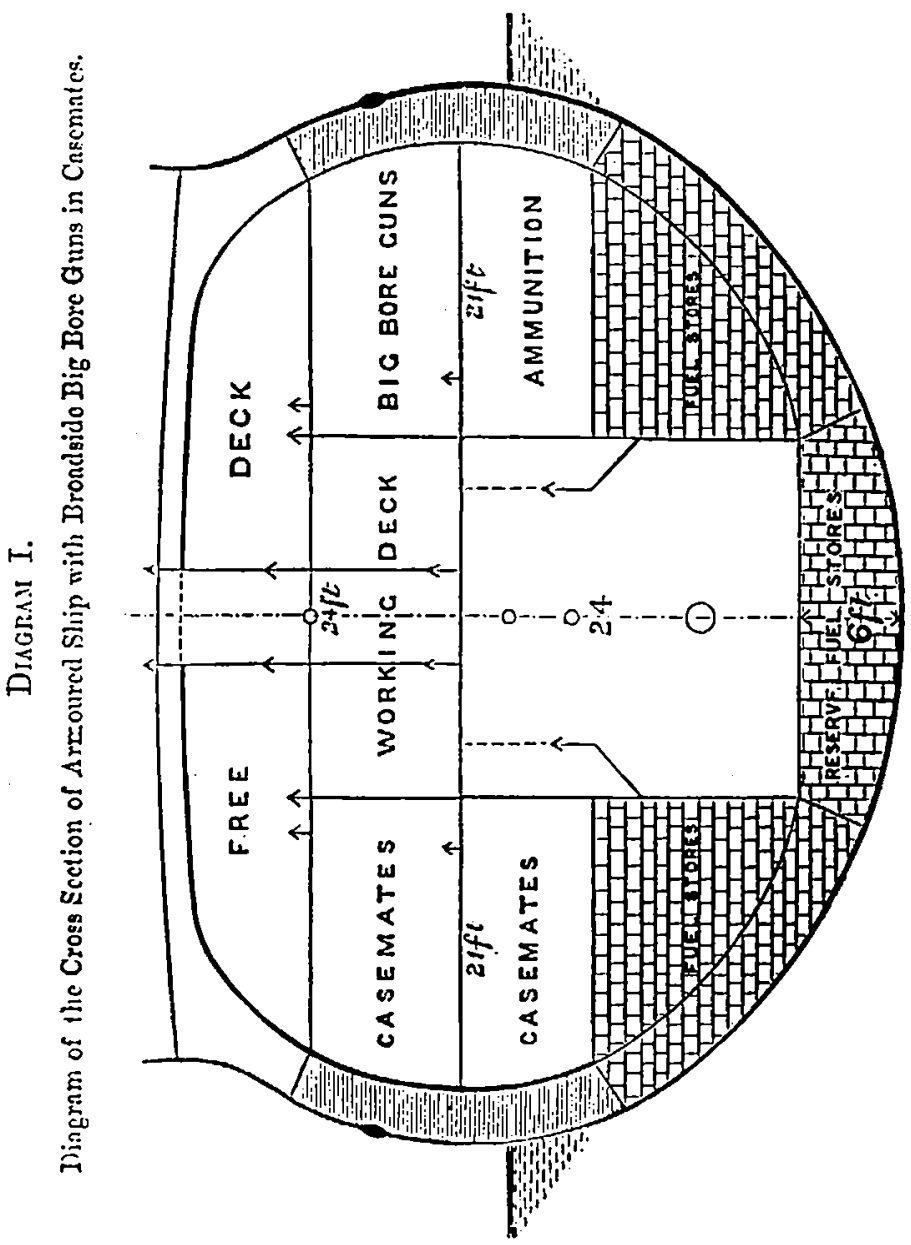


220 square fect of deck; or if 10 fect will do for the gun call it 10 fect by 22. Height between decks. we need not now fix. M5 first step for safety which I am ready to take, is to diride the whole broadside of the ship into casemates of 12 fect each, and to place in each one its own big bore shell gun. I can so arrange tho structure of those case. mates that they shall add nothing to the dead wcight of tho ship, bat, on the contrary, give it uscful strength.

These casemntes will hare these characteristics. Entry only from abore. They will be water-tight and air-tight. Encmies' shell exploding in one will not reach the rest. Water cntering one will remain there, not sprend to the others.

This casemate system I do not mean to confine to this gun deck ouls. Each casemate shall havo under it, an underwater casemato containing all shot, shell, charges, and stores pertaining to that gun, and to the ship's company of that gun. During battle no one need leare that casemate but one; that one stands on the apper deck, or at least has his head abovo it, and sees and knows all he should, and has complete command of his gun and gunners below. Thus wo hare norr a unit of our war ship. We can carry in trenty cascmates, cach 11 feet by 20 feet, twenty big bore shell guns.

We can carry on the other side twenty more. Thas, in a ship's midship body, 220 fect long, we carry forty. big bore shell guns. If one broadside of such shclls do no liarm to our enems, ho must bo hard to harm, we have no choice left but run him down.

$\Lambda$ to our own protection. If he is run down we are safe. If we miss and he shells us, look at our position. If he nim well and pierce us with one of his four great guns, he may disable one of our gans and harm the gunners. But that is a loss of 1 in 40 , not 1 in 4 , which is his loss if we harm his gan.

Now this casemate system is all we can do, and should be fully carried ont in erery ship laving big bore shell guns in grent force. It mast be extended to the boiler-room and engine-room equally. Instead of communiciting everywhere, the boilers of a large ship must bo shat in all round so that when explosion comes from causes without or causes within, the explosion shall confine itself to that one closed chamber. This I did in the Great Eastern, and thereby I sared the lives of the multitude then on board. Each of the five distinct scts of boilers was entered only from abore, and enclosed in a rater-tight cascmate. A foolish auxiliary boiler, meant to save a lit'lo scrap of fuel, and ealled a superheater, was added to the ship's boilers by the owners of tho ship in opposition to the judgment and contrary to the advice of the builder. It blew up, as it should havo done, and toro open the adjacent boiler and killed the men in the engine-room. But, thanks to the complete seclusion of that one set of boilers in their orn closed compartment; we who were outside, and we were many, escaped, and the rest of the boilers and machinery continned their work unharmed, and took the ship to her destination. It is, therefore, not from fancy but from hard facts that I entreat you to save the lives of your men on board your ships by the means which saved mine-the system of cascmates and closed compartments cntered only from aloove. 
I have carried out this system throughout the plans of scveral ships, and I cannot say that I find any disadvantago at all compamble in value to the safety of life and secarity from sinking, which it, and it slone, can give.

But I am bound to tell you that the planning and working out such a system has ono disadrantage. It requires much forethought, foresight, and skill in those who plan it, and mach of the same qualitics in those who uso it. Bnt in this it resembles all other improvements which are new, and to which we have not been practically edueated and trained. It requires time to mature its structure, its use, and its nsers, therefore the sooner we carnestly set about it the better.

Theso casemates clothed in armonr will carry each a great bore gun, and a similar casemate below the water-line will carry ammunition for that gun. 'The sub-divisions of the ship's hold going down to the ship's floor, and going right across the ship, will form continuations of these casemates, and thus the whole will be one homogencous structure of wrought iron plate, disposed in the best way, witlout waste of weight, and each part contributing its full share to strength, safety, and cffect.

\section{V.}

Strength of Armour ancl Ship).

Giving up as fanciful all ideas of perfect impenetrability, we go into the plain problem of making tho best of what we can have. If $\mathrm{J}$. can carry 1,000 tons of armour in a given ship, low shall I best dispose it?

1 have so much area to cover, so many guns to protect, so many tons dead weight to carry.

Here the practical problem begins and ends, how to make the most. of say cach 50 tons of armour.

The gan I have to protect occupies a casemate, having an exposed face of say 100 square fect. If cach foot of armour over a foot thick woighs $5 \mathrm{cwt}$, that will use 25 tons, learing 25 tons more for end-on aud ander-water protection.

The question is now this, how shall I best utilize these 25 tons over 100 feet of face, so as to be most criduring. The answer's to this are most important :--

1st. What shall the armour be? hard iron or soft? irou or steel? or both?

On this I shall give you the. sum of $\mathrm{my}^{\circ}$ own cxpericnec and of others, as far as I know theirs.

1. Joints in armour are weak places, therefore let us make them the strongest.

2. Bolts and bolt-holes are causes of cracks and giving way, therefore do away with bolts and bolt-holes.

How this may be done? Our system of casemates cnalles us to do this.

A modern armour plate covers over 100 square feet, in 'one single pice, it weighs 25 tons. But it is pierced with holes, and its joints 
The Cros Fue Molldyut and Aravor.

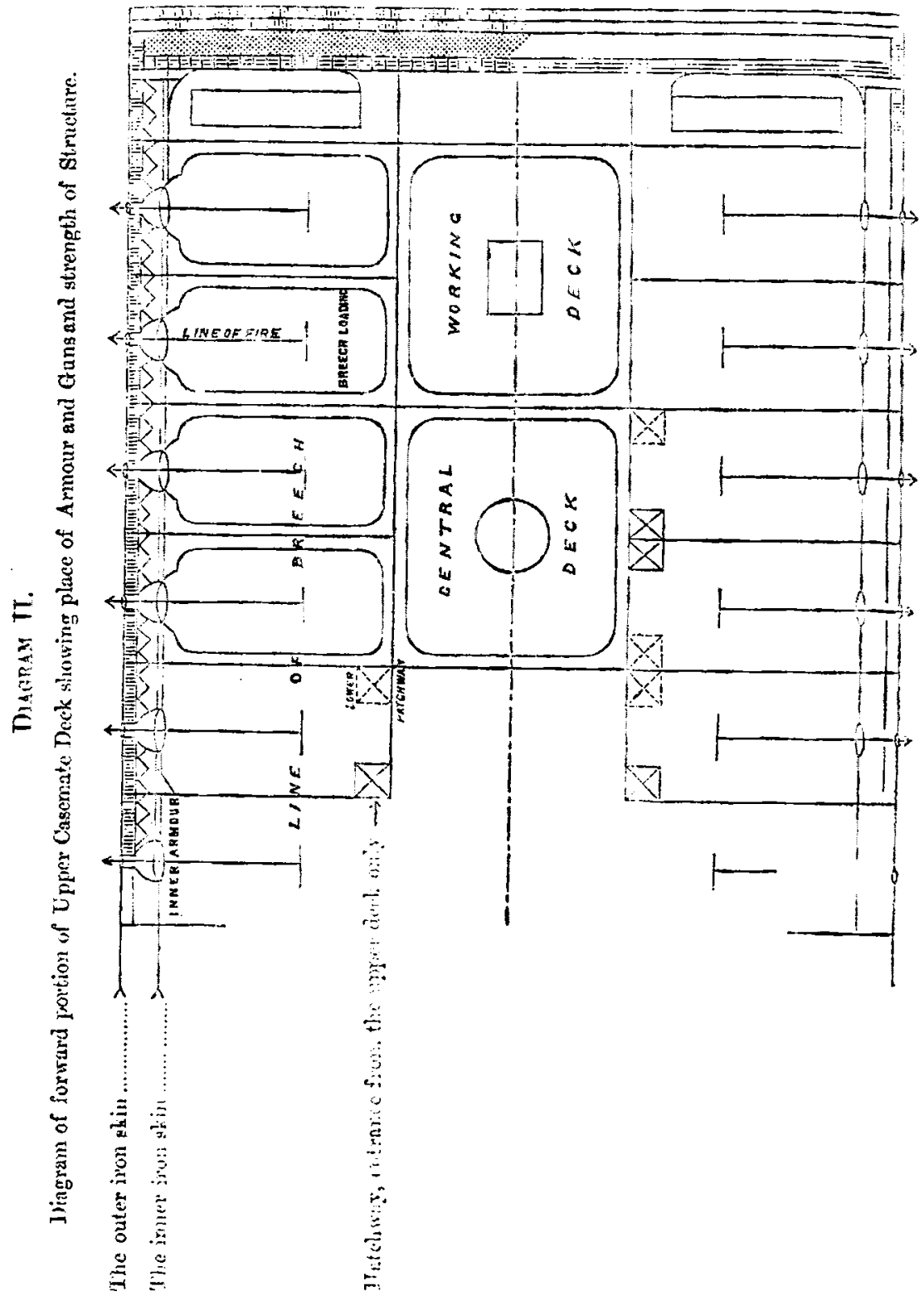


nre weakuesses. Struck on a joint it gives in there and flies out at the far-off edges. Struck between two holes it eracks between. Now if we place the whole four edges of the plate on the four walls of our casemate, all four thus supported, become tho strongest place in the platc.

If therefore it be true that the strength of overything is measured by that of its weakest part, wo have by our casemato sjstem much strengthened our armour.

Next, as to the quality of our armour-plate; shall it bo hard or soft? steel or iron?

This question requires careful discrimination. Doubtless the harder it is, like tempered steel, the more it shatters the shot of the enemy. But also we must remember that hard stuff cracks, and so, though the shots of the enemy are shattered, yet later on, our armour is itself shattered, cracks, and falls to pieces.

Our question therefore comes to this, can we get all the advan. tages of steel armour, and yet protect our armour from crumbling to pieces?

First then we must fasten it to our ship without bolts or bolt-holes; next wo must hold it in place by such means that thongh split ly shot, tho picces may still bo retained in their places, and do thoir work as armour.

There are several ways to do this. One I tried at Shocburyness was an edge binding, where the plates were rivetted in places without bolt-holes, and it certainly resisted better than any of the others. But there is a much better way not yet put into practice.

This way, which I propose should bo put into practico along with the casemate system, is to incorporate the armour-plate within the structure of the iron plates of the ship. There need be no armourplates nor joints visiblo outsido the ship, only the common iron skin quite smooth on the outer appearance of the ship; then the ship itself built, like the Great Eastern, with broad plates at right angles to each other, and forming a cellular skin. The spaces of this cellular skin to be made of such sizes as each to hold a large armourplate and its backing, and this entire skin and its divisions built up of iron plating two or thrce layers thick.

By this system of incorporating the stecl armour or iron armour inside the hollow walls of the ship's side, tho armour would add to the strength of the ship's structure, and the ship's structure would enclose tho armour without piercing it with holes and making it crack, and if it were cracked by somo extraordinary force, the two or more pieces of the cracked plate would still be secured fast in their place, and would still bo there to reccivo the blow of the next shot, with diminished strength, but not destroyed nor removed. That I think would be the way, in union with casemates, to make both the ship the strongest and eafest, and the armour most effectire, secure, and durable.

Thus 50 tons of armour gives us protected casemates for, one gun of the twenty guns in twenty cascmates for the weight of 1,000 tons of armour. 
I think that by means of this arrangement we have mado the unost of our money, weights, and material.

Of course double these wcights and cost would gire double thickness of armour, but the same methods of application would jield similar advantage in use, should such weight be decmed cxpedient. But that question comes later, when we settlo the size of ship.

VI.

The Dran-of-War.-Ship of tho Line.

In designing a ship of war, the first masim I should cntreat you to ndopt would be, not to allow any of tho usual prejudices in farour of or against any particular proportions, shapes, or modes of construction to affect your minds, bat to follow out implicitly the conditions and wants of the case and the nature of the work the ship has to do.

1. Lot us agree that the ship shall have the shaps, proportion, and qualities of a sea-going ship; shall stand up well nnder sail and roll casily with the sca; shall be dry and handy. We know that these qualities have been completely obtained in many ships of the past.

2. Lret us agreo that our modern man-of-war must go fourtecn knots under steam. This settles tho shape of bow and stern; the length of entrance and run, 200 fect.

3. Let us agree that our ship must carry fuel for 3,000 niles, 4,000 miles, or 5,000 miles. That settles whether sho is to bo 30.2 fect long or 360 or 400 feet long. Sce diagram III.

4. Let it bo agrecd that she must carry 2,000 tons of armour and 2,000 tons of armament and ammunition. That settles her breadth of beam as say 64 feet.

5. It must be understood that the rniddle body of the ship protected by armour should bo adcquate to securc the ship when the unprotected cuds are shellch.

Tho result of theso conditions, without any choico on your part or mine, give us a-

Ship of tho line 66 fect beam, 24 feet draft, $300,360,400$ feet long, the length of the ship being proportioned to the length of tho voyage she can make or the timo of her endurance at work.

The entire water-borne weight is 12,000 tons; the weight of ship, equipment and engines is 5,000 tons; armour and armament, 4,000 tons; fuel for ocean voyage, 3,000 tons.

This store of fuel is good for 6,000 miles. Diminished length of 10 feet of ship makes 300 miles diminished length of royage.

Thas built of 300 feet long, this ship is good for only 3,000 milcs steaming; 360 feet long for 4,800 miles steaming; 100 fect for 6,000 miles steaming.

Now on tho point whether you would prefer the longer ship, to cnablo you to scek your encmy further, to follow him faster, to chooso your timo with nore margin in hand; all theso are points for your choice, not mino.

Let us now see how wo can turn all this weight of carrying power to account. We hare 4,000 tons for armament and armour: saj 2,000 tons armonr, 2,000 tons guns, ammunition, and stores; 1,000 tons 
guns and carriages; 1,000 tons ammunition, \&c.; bcing 10 guns of 100 tons, or 20 of 50 tons, or 40 of 25 tons.

I have already said how I should wish to see the arnour and protection carricd out and the guns placed broadside in cascmates. But the question of choice of guns is more yours than minc. I prefer a given weight of large-bore gun firing largo shells with high initial rclocity at close quarters, brecch-loaders, and placed in rery simple carriages in armoured cascmates, to all the complex mechanism and misplaced ingenuity of firing long, narrow, thin shot, from long distances on a heaving sea.

It will be secn that if this ship, 66 fect beam, wero only six beams in length, which wo have always reckoned a very modernte proportion in steamships, she would bo 396 fect long. But it is objected to length, that it cannot bo combined with quich tarning or inanceuvring power. Now this is truo in degree, but in degrec only.' I can quite undertake that the turning power or manouvring power of our warships can be made such that a ship 400 feet long shall tume round quicker and sharper than our present war ships of 300 fect long. How this is to be done I shall consider further on.

Talle of Dimensions.

I. Tue MLar-or-IVal:.

(66 fect beam, 25 fect drauglit.)

\begin{tabular}{c|c|c|c|}
\hline Lengths. & Bearing Power. & Stcaming Power. \\
\hline Feet. & Tons. & Niles. \\
300 & 8,000 & 3,000 \\
360 & 10,500 & 5,000 \\
396 & 12,000 & 6,000 \\
\hline
\end{tabular}

IIa. THE Firg.ATL.

(56 fcet beam, 25 feet draught.)

\begin{tabular}{|c|c|c|}
\hline Irengtls3. & Bearing Power. & Stcaming Power. \\
\hline Fect. & Tons. & Milcs. \\
300 & 7,000 & 3,000 \\
360 & 0,000 & 5,000 \\
306 & 10,500 & 6,000 \\
\hline
\end{tabular}

IIl. The Fingatr.

( 16 feet beitu, 25 fect draught.)

\begin{tabular}{c|c|c|c|}
\hline Iseugtlus. & Bcáring Powcr. & Stcamiug Power. \\
\hline Fect. & Tons. & Jijles. \\
300 & 5,500 & 3,000 \\
360 & 7,000 & 5,000 \\
336 & 8,000 & 6,000 \\
\hline
\end{tabular}



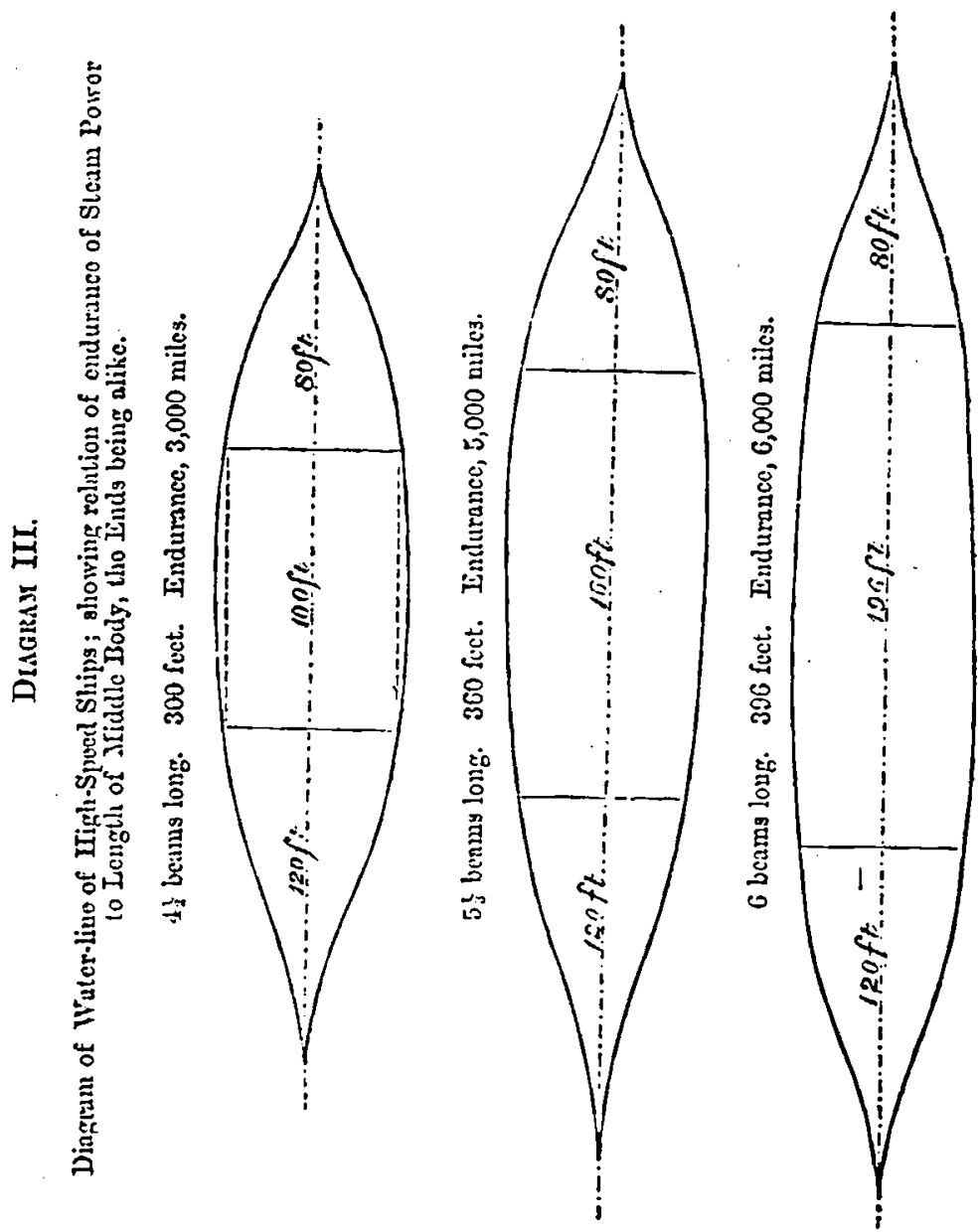


\section{VII.}

\section{Gunnery and Mancuures at Sea.}

All my experience of the sca, (and I am rery fond of the rrares and cnjoy their play,) has given me tho belief that with our present large guns, very littlo good is got by complex mancouvres of the gun. To say that the gunner can lay his gan as ho used, by peeping throngh the port and adjust it with all the nice precision of a land gan, is sheer nonsense, and, if $I \mathrm{am}$ well informed, all such sea-gunnery is sheer waste.

I have come to the conclusion that the modern ship is the true guncarriage, and the chief gunner is the man who commands the ship, and that the guns of the ship are laid just as the ship's head is laid.

I beg you, therefore, to go back with me to our opening sea fight. I presume that on entering that engagement, the Commander had four large bore guns laid right a-head in the line of the keel, and that as he kept her head direct on the eneing, stem to stem, so thej only received a signal to fire and reload. Being brecch-loaders this could be dono without deranging the gun, and without loss of time. But I fancy the firing may have been wisely reserved. I presumc, also, that the Commander on sighting the enemy, had all his trenty or forty broadside guns laid right across the beam, and at such eleration as the state of the sea rendered most serviceable. Some talk of converging broadsides as aseful, I prefer square across the beam. Now the Commander of the slip, standing where he should, sees all that happens without, and guides all that is to happen within, knowing now how erery gan lies, and haring only two such ways to think of, he is, I think, quite master of the situation.

He has only to see the ship's head right in line with his enemy to fire with certainty, and if he do not give him tho stem but pass him, he will surely deliver into him the entire broadside.

Now all this is coolness and courage, and forethought and wisdom, but it requires no tricks of gunnery, and no marvellous, ingenious, costly, complex mechanism of any lind; its sole virtne is simplicity, common sense, and cool conrage.

In this ease then, and in 'many others, I call the ship the guncarriage, and the Commander tho ganner-in-chief, and thus I dismiss all bewildering complications.

Being breech-loaders, the guns are at once reloaded withont being in any way shifted or altered, and one minute may suffice with good organization. All is again ready and nothing changed but the ship's place, and the Commander is giving the guns the proper direction by the ship's head.

I wish bere to say a few words about tho ports of armoured ships. The ports of which I made the designs, were made small and narrow; I hare lately seen the ports of armoured ships mado wide, open, and largo; and I hare even seen them shaped with funnel-like'mouths spreading ont wide, just such as I should like to fire into if she were my enemy, for I could not fail to fire my shell right into her central battery, even with my clumsy aim. Now, I have a growing conriction FOL. IXI. 
that we cannot, in our armoured ships, too much diminish the size of our iron-clad ports. Years ago somo of us contrived mazzle-pirots for our guns; the principle has been revired, some foreign gorernments hare tried it with success. I can conceire nothing better for an armoured cascmato than a closed port and a mnzzle pirot, no smoko and no bullets could then enter, and the gun, already laid in an already ordered line, would obey the orders of the gunner-in-chief. On this arrangement I place ligh value; any of its secming difliculties are casily got over.

By arrangements such as these, difficulties of gunnery and guncarriages, and laying and loading, speedily disappear, and the Officer in command may feel that he is in real command of his ship, instead of feeling himself tho victim of mechanism and machinery over which lie can exercise no control.

What I have here said relates chiefly to tho guns in casemates of the ship of tho line. I may afterwards show its important bearing on ships of a smaller class. Tho four chase guns at cach end of the ship mas havo longer range and wider training.

\section{Another Kind of Fight.}

There is one way to aroid ramming and boing rammed-" running away."

Thero are cases in which running awas might bo wise. You aro stronger than me, I am faster than you; I ran away, you follow, and I cscape.

But though I may secm to jou to run awaj, and you follow, I may choose to fight jan as I run. I may have good armour cnd-on, though I may have nono brosdside (or little). I may also have good guus end.on. In this case, though you haro also good guns and plcuty of armour, I with more speed, am a match for you.

This may be a good reason why I seem to run away. I may fre directly into you withont changing my course. I by speed can keep ncarer you or farther off. I, as I go farther, may nise vertical fire, falling on your decks. Thus with little armour I may match you by speed and good armament and simple armonr.

\section{VIII.}

\section{Other Kinds of Ships.}

If wo have war-ficets at all, should we have any but tho most powerful ships, with most speed, most great bore guns, most completo armour, most endurance at sea?

I must confess to you that the deeper I go into the question, the more I come to tho conclusion that the first-rate war-ship, thongh the most costly, is tho best worth her cost.

I mnch prefer ono strong ship to two weaker oncs.

For tho naval strength of our great empire, I can sce no war-engino comparable to a flect of ten or twelre ships of tho line; all identical cach to cach in orcry point and quality; all searrorthy, fast, and onduring; all with many large boro guns, and complete unsinkable 
hall and armour; all able and ready to go round the empire and fight whenever they can find an enemy, quiek and handy.

Among other possible ships, are ships of the same length, of Iess breadth onls, and having the same qualities. Theso wo mas call frigates, and their only difference is-wanting complete armour.

is " complete armour" let us agree that wo mean a middle body with all in it protected, and long cnough to sustain itself and the foro and after ends of the ship.

By" "partial nrmonr" let us understand:-

I. Two transererse sections fore and aft, protecting all decks, engines, and magazines from cnd-on fire; call that the lowest degree of armour.

II. The next degree should add to this, armour for magazines, cngines and boilers, and an armour deck covering them.

Tho higher degree let us call complete armour. I shonld give as a rough estimate-that the complete armour bcing 2,000 tons, the 2nd rate armour would bo 1,000 tons, the $3 r d$ rate armour 500 tons. Now wo see that the addition of the complete armour, as compared to its lower degree, is only a difference of 1,000 tons, in a displacement already of ten or eleren thonsand. So I conclude that the advantago preponderates for complete armour in the larger classes of men-ofwar.

The sccond class of armour-clad is the frigate. Its two bulkheads giro it completo end-on protection. Its casemates limit the dangers of the exposed side. Its low armour orer magazines, engines, and boilcrs secure its ritals oren from broadside fire, while its ends save all within from raking and sweeping fire. It is uarrower and cheaper than a first-rate.

Now this class must be the fastest of all. It must be able to follow and catch any ship it wants to get hold of. It must be able to get away from ressels able to sink it. It must be able to return to us before our enemy can follow. It must be able not only to elase with effect, but to be chased with impunity; its chaso guns and its two bulkheads give it this power.

III. Whether this class should be classed as corvettes, and a smaller class called sloops should be emplojed chiefly as intelligence ships, with no porrers at all except that of running away from armoured ships, is a question I must leave to others. I would rather omit such ships altogether from the fleet, and inclnde them and all others ander the general head of Special Service Ships-mortar-boats, torpedo-boats, under-water boats, monitors, turret-ships.

I doubt if much good is got by going down from ship of the line to frigate. It is cheaper and less wide, that is all.

Bnt we may want a ship of less draught of water, and greater speed than oursclres, to form the flying squadron of the fleet. If ive are taking charge of somo sea-The IIediterrancau, the Indian Ocean, the Nortl Pacific, the Australian Ocean, the West Indian Seas-we want ships to bo evergwhere, to watch everything, to deal with smaller cnemies, and to protect our own smaller interests; wc mast have a sort of ubiqitous ship-something like the German Uhlans, which I used to 3 i 2 
sce on the outlook, all over Franco during the war. It secmed to mo just what we must do with ships in seas when we have to make war.

\section{IX.}

Slips for Exceptional Service and Special Duties.

\section{Mines and Shells.}

The question of torpedoes, mines, and under-water attack is one which no Commander of a ship and no constructor of a Navy can neglect, but it is also ono which has attracted much more attention by nerrous excitement, alarm, and fear, than by real forco as an instrument of Nrval rrar.

As erer since the beginning of the Crimean War I have given mueh study to the question of under-water warfare, nllow me very shortly to deal with this matter as it regards fleets. There are many engines of mar which are quite as dangerous to the enemy as to us: mines and explosives generally are of that nature; shells and explosives generally are of that naturc. I will try to put all I think useful to you in that matter into few words.

From my own personal knomledge and experience I can tell sou thus mnch. If you are my enemy and lie near my shores in smooth water, I can, with a very small ship or gunboat, do the following things to you :-

lst. I can firc large explosire shells upwards which shall fall vertically downmards through your deck and explode in the midst of your ship.

2nd. I can send theso same shells horizontally abore water and strike sou horizontally about the water-line, hbore or below.

3rd. I can send these same shells down below water, right under. the bottom of the ship, and there explode them at the same moment at which sholls are descending and exploding from above.

Now all these things I can do with certainty and not without risk, if you allow me; but I need not add, that jon are a fool if you allow me.

Allow mo to say thut I think these are much more matters of fright than of fight. Rockets frighten savages more than ballets. Greek fire was a grand causo of alarm in old times.

I should make myself well acquainted with all such matters if I were a Naral Officer. I should amnse msself with them, and mako my men quite familiar with them, and ablo to use them to frighten the encmy", but I should not trust to them as an instrament of serious warfare.

The one answer to all is-destroy your enemies before they get near yon. That casy task I learo to you. That erery flect shall be composed of a different class of ship, charged with different kinds of duty is now plain-that is a matter of naral strategics on which I need not enter. Bat I have no doubt that it will be the duty of tho numerous classes of small ressels of the flect, to see that no small ships of the encmy come near to the main body of the ficet so as to shell them either abore water or under water, torpedo-wise or otherrise. 
If great ships allow little ships to come near them and shell them they deserve to be sunk. $A$ torpcdo-boat is as easy to sink as auy other boat, if not easicr.

All I have to say in the matter of ship-construction is this-that every ship of war must be planned with full knowledge of the fact that the shell is the engine of naval warfare. That it must be thromn ont in whaterer dircction will givo best effect, and that protection must be afforded against shells from erery direction in the manner we find to be most effectral.

In overy case there remains only this one rale of war"Sink him first."

There is no other.

$$
\begin{gathered}
\mathrm{X} . \\
\text { Gun-B்ats. }
\end{gathered}
$$

I rank the gan-boat, with one big bore gun, as the class of war vessel next in importance to the ship of the line.

There is this important distinction between them-the fleet of large men-of-war is ready and able to go to any of the seas of the British Empire, and there to win a victory over the fleets of any of the enemies of our power or our commerce. But the fleets of small ships must be localized, they must be already in tho place where our interests lie. They cannot carry coal to steam thousands of miles. They cannot accompany the ocean fleets, they must precede them. Local flotillas of our modern gun-boats I cousider as a good school for tho fature training of the crews and officers of the Imperial Navy. In our great stations in the Indian ocean, in the Australian scas, at the Cape, in the West India Islands, as well as near our own homes, there should be completely organized flotillas of the smaller classes of war vessels, in good harbours and well-protected stations, to wbich in caso of war our large men-of-war flects might bo dispatched with the highest speed, and find these fortresses and their local flotillas ready to join them with perfect equipment, and ably manned and commanded.

The question of the constraction of this class I consider to be one of the higlest national value. I venture to call it-

\section{The Unit of the Ileet.}

It is tho smallest ship, but it carries the largo bore gun, equal to that in the largest man-of-war. The reason I do not follow the common course of placing a small gun in a small ship is this-that the boro of the gun is not settled by the size of tho ship that attacks, bat by the strength of the ship it has to conquer.

As our unit has to attack the largest and strongest ship, it must have a gun fit to fire a large bore slell with a high initial specd, other- wiso little bore guns against strong ships are worthless.

The noxt point of importance in this unit of the flect is that the gun-boat shall be the gun carriage. It needs no other. The boat built with a strong thick iron bow will bo the gun carriage, and 
the water in which the boat floats will take the recoil, no other is necded.

'The gun bout being the gun carriage, must be cleverly handled by an able gunner and a clever commander. Therefore also tho manoearring power of the ressel must be made \& first object of design and construction. Ordinary screw propelled boats have many disadrantages in handling them. These the ingenuity of Fngland must be asked to remedy. It is to be remedied in severnl mass, and a little experience will soon show which is the best.

Assuming that this one-gun ressel is taken as our unit, aud that her gun has 15 inches bore, and 18 or 36 tons weight, the ressel herself will hare to be not less than 25 fect beam, and probabls more than 150 feet long. But with that short length, she will ucither hare ligh speed nor endurance of fuel for length of run.

Calling the one-gun boat the unit, I think it rery important to haro another class, which I will call the twin-grun boat, because she will be able to mount tro of these big gans, one fore and the other aft, and she will be able to go with equal speed either war, and be capable of manoedring equally well either end foremost. She will have to be longer, and she will be able to make a longer vojage with a greater store of coal, and though she has more length than the unit, she will manceurre equally well, from being able to stem cither end foremost at full speed with full manoenving power.

But with these qualities, let it not be forgotten that a singlo large shell sent into ler centre by a first-rate man-of-war seads her to the bottom.

In this respect therefore tro nnits are better than one twin.

In conclusion, I think a ferv handreds of such gan boats all round our coasts would make good seamen gunners of ns all.

\section{Conclusion.}

If I may now venture to sum up the conclusions to which I should desire the present discussion to lead us, they are the following:-

1. That the construction of ocean flects of men-of-war, able to keep the sea, in all the stations of the empire where British rule and British interests requiro protection, is a matter of national as much as professional interest.

2. That the creation of a now fleet or fleets as distinguished from the maintenance and repair and restorntion of existing flects, is a great national act rather than a matter of ordinary ndministrative routinc.

3 . That the creation of an ocean flcet or flects is not to be accom. plished without a great national effort, in which the industry, the commerce, and the financial resources of the country, as well as its professional abilities, must all be brought into cordial and patriotic co-operation.

4. That a standard Naral gan of large bore and light weight, breech. loading, and so arranged as to fire through a small closed port, and worked by simple means, is a desideratum in the Naval service.

5. That a s5stem of Naral casemates, enclosing broadside-guns, haring steel and iron armour, the armour so incorporated with the 
ship's side as cach to contributo to the strength of the other, offers grcat sccurity against shot and shell, and much safety agaiust ramming and sinking.

6 . That a similar system of dirisiou and subdirision, in the compartments of boilers and engines and in stokeholes, coal bunkers, and tanks, offers the best sccurity against dangers from within and without.

7. 'That a speed of 14 knots should be tho normal speed of an ocean flect, and that a minimum stcaming power of 5,000 miles, should be the normal endurance of the steam ships of the flect.

8. That improved manourring power in screw men-of-war, is a desideratum, which may be accomplished in sereral ways, and which deserves to be mado the suljoct of study and inrention and trial for use in the serrice.

9. 'That a large and powerful sca-kecping man-of-war, and a small quick one-gun boat or twin-gun boat, are the two most important units of a nars.

10. 'That the large squadrons of the flect should bo ready for service in every sea of the British Empire; while the small vessels should bo localized in well defended Imporial stations-placed where the most important interests have to bo defended.

11. I submit that a man-of-war can now be constructed with a speed of 14 lnots, an endurance of 5,000 to 6,000 miles steaming, the sea-going qualities of a sailing ship-casy, stable, and handy, carrying 20 to 30 big bore broadside guns of 15 inches, all under complete armour, and an orer match for any existing man-of-war, under 396 feet long, and able to turn round quicker than existing and shorter ships.

12. I also submit that we should adopt the one big bore gun boat and the twin-gan boat with high speed, cxecptional turning power, and speedy reversional power, as the unit of our flotillas of small men-of-war.

The Cramsax : After tho very interesting lecturo we late heard, and the instruction we hare derired from it, I hope there aro many gentlemen present who will contribute to our information. Esen if they do not agreo with the lecturer, their criticisms will doubtless gire us still further information on this interesting subject. Thero aro one or two points I should like to hear something more about. One is as to the strength of theso cascmates to resist the explosion of a sucll. It would resist, perhaps, water, but would it resist the explosion of an encmy's shell that camo in from aboro?

Mr. Scorx Ressele: It will, nol without injury to itself, but it will not injuro those that are around it. It will be bulged a little, but it will sare thoso abore, it. $I$ hare been in a ship where a large explosion of this kind has taken place.

The Crainyas: I should also like to know how the casemates are to be rentilated, for we know the diffieulty of getting men to work in places where there is little or no rentilation; and aleo, as cach gun-cascinate las its oxn magazine in the cascmate immediately under it, low is that cascuate-magazine to be lighted, rentilated, and prescrved from explosion?

Admiral Lord Dexsaxs: Perbaps Mr. Scott Russell will bindly explain what secms to me at first sight a difficulty, but which is probably no diflicults whaterer in the wind of an enginecr. Mr. Scott Russell proposes to interpose between what we may call the two skins of the elip-the armour plates. Now, as I conccire the building of an iron ship, the two shins ure here nud there connected torether, and that counection gires them rery much of their strength. So far as that place is 
concerned where the amnour plate is put in, it appears to me that the two shing will be ecparated. That is to eay, I belicre the lecturer did not proposo that the armour plate should form any connection whaterer between the tro skins. I see I am right in supposing that the plate is not to connect the tro in ans was, thercfore; as it appcars to une, the tro shims are separated, so far as that plato is conceracd, without any of the usual strengthening pieces to kecp them together. Probably Mr. Scott Russell will also explain . whether, as might suggest itself to some people, there is not a loss in presenting to the cnemy ordinary plate iron as the pièce de résistance, instead of the ammour plates. Is it is now, the enemr's shot will come into contact with the armour plates; under the proposed plan, the shot are to strike upon the ordinary iron plates, or possiblo iron plates. I think I understand the lecturer to Eay tro or three thicknesses together, but still, cf course, they mould bo a frail protection against shot. Those are two things that no doubt come within the knowledge of an enginecr, but which, to a lay obserrer, ecem to present a difficults. 'There is another point of naral engineering of which $I$ do not pretend to hnow ansthing at all, but in diamram III one sees that whereas the midship portion rarics 100 per cent., one being 100 feet, and 2nother 106 ; in erery caso the run and tho bow preserre the same length. 'That, of course, runs a little counter to one's ideas of naral srminctry, but $I$ suppose there is an answer to that, and no doubt tho lecturer, when the time comes, will farour us with it.

The Cinirjeas : As Mr. Reed is present, we shall be rery happy to hear ang remarks he may wish to make.

Mir. E. J. REED, C.I3., M.P.: I really am unable to respond in any manner, such as I could wish, to your hind invitation, after tro hours' sitting in a close room on a ters hot day. If the discussion is adjourned, I shall then be rery happy to take part in it; but the paper has so many points with regard to which I must respectfolly differ from the distinguished lecturer, that I should not think it falr to him or to myeclf to enter upon a discussion unless one bad a reasonable opportunity for stating the contrary rien.

Major-General AlexANDEr, Royal Mrarines : I slould like to be permitted to ask the nanner in which the lecturer proposes to protect tho guns within the cascmates from diagonal fire. I understand perfectly it is proposcd to protect the guns and gunners from direct fire by armour plates of ccrtain thickness, but I mas unable to catch the modes in which the guns and gunners wero to be protected from diagonal fire, which fre, I apprehend, would be as dangerous to the effeiency of the ressel as that which mould be absolutely direct. There is one part of the lecture which pe have just heard, that deserres epecial attention, and that is where such stress was laid on the great necessity for organising and localising not only onr colonial defences, but the shore defences of our own country. For if mo reflect upon this question, I think it will bo found that ererything of the kind resolres itself into a question of mones, and if $\pi c$ leare until war breaks out, all the organisation that becones uccessary for this particular bind of defence, an enormous amount of money will be necessary and at the same time the rrork must bo ineficiently performed. I am interested in this matter, because some fifteen years since $I$, in a humble manncr, endearoured to bring formard that particular question, and to show the desirability of ecparating the const defence of this country and the colonial defence from the system of a sea-going narg. It has almags appeared to me that the necessity cxists of haring vers large ressels, in order that certain sea-going qualities may be obtained, and that a certain poirer of coal-carrying also should be gained, both of whicls aro utterly unnecessary in a cosst-defence reszel. But by organising a special fect for that purpose, wo are able at once to arrive at greater speed, greater defensive porrer, and greater gun power, and at the same time we are able to separate the organisation, and hare a force of oflicers and men totally apart from those requircd for more spccial serrice on the ocean. I think that is really onc of the most raluable parts of the paper. Perbaps it is that I am less capable of cntering into the construction of the ship proposed, and of secing the many raluible points in connection with it.

Captain Price, R.N., M.P.: The lecture we hare all listeued to with so much attention has trarelled orer such an innumerable range of subjects that it is quite impossible for any one person, vithin a rery short space of time, to reply to more than one or two of the different points. I think the point abore all others which 
3Ir. Scott Russell has dealt with, and rery rightly, is the irresistible porer of the ram; and I should like to say one or two words about that. I think that the shape which he gires to the bow of his ressel is not one that is unanimously accepted in the serrice. The prerailing fecling, I think, at present is that the bow which he has discarded-the snout under water-is that which is generally preferred. But he, 25 a slip builder, tells us that he docs not think it is a safe form, and he las giren us his reason-that he thinks it can bo casily mrenched of:. I hope Ir. Scott Russell will not think it is a personal remark, but I was going to say the line he generally takes is this, that he comes here as a ship bulder speabing to naral officers, and he says, "If jou only tell us what you mant, wo can do it for you." IIy point is this, if it can bo slown that naral officers prefer that particular kind of bow which $I$ call the underwater snout, I have no hesitation in saring that MIr. Scott Russell, on his omn showing, and other shipbuilders, can build a ressel in the particular form that $I$ say we want, and without any danger to the structure of the ressel. That is my point. Now, I just want to say, in oue or trio words, why I think that form of bow is to be preferred. Taking Ir. Scott Russell's omn diagram of a ship, of the bow of the resscl that is to attack that ship, is something appronching to a straight line or slight curre, it is rery nbrious that if this ressel happens to be rolling a little towards the ship that is attacking her at the time she is struck, she will strike a portion of the ressel rers likely abore the mater-line, and will not run the chance of damaging her under rater half so much as if the ram bow of the ressel formed a line comernat similar to the section of tho ressel that is to be struck. Thero is another point. We cannot almars assumo that the blow struck will be sufficient to sink the resscl. That depends a great deal upon the way the ressel is built, but it may do her a consider. able amount of damage. It may damago the vital portion of the ship, and I want to ask where are the rital portions; are they abore the water-line, or are they not rather below it? If the ghip is struek in any part under water, the chances are not only that $n$ rery large hole will be made, but that the engines might bo displaced, the boilers might bo burst by the concussion, and certainly such damage would bo done to the ship as tliat it rould be rendered hors de coinbat. One other little point in connection with that. Taral men are trying to find some means of quickly stopning the rent made in the side of a ship by tha blow of a ram. It is rery necessary, of course, that that should be done, and a certain amount of success lins at tencled the effort of naral men, both in our own and in foreign naries. Now would it not be rery much casier to stop a rent so get-nt-able as one would be aborc the water-line, than to stop one rery nuch below tho water-line, where it cannot be so casily got at? Those, I think, are the pints deserring attention in the ramming, borr. Another rery important point that the lecturer touched.upon was that of gun-boats. Now that is such a large subject that I rou't go rery much into it, but I wanted to make one remark about the power of directing those boats. Mr. Scott Russcll and others lnse adrocated that, in certnin cascs, with swall gum-boats, it might be as well to dispense with the ordinary gunearriuge avel the training power of the gun, and to build the gun, so to speal, into the ship. I do not think that that is a bad plan at all; but I would say in the uary, as far as I hare ecen, there has not been sufficient attention paid to the porrer of dirceting the fire of the guns, not from the gun itsclf, but from some of the points of the slip. It is a rers difficult point indeed, and it is one $I$ am not quite sure whether I wight not say should be taken up by the constructors of ships in conjunction with gunnery men. Then as to the rertical fire. J[r. Scott Russell raised a smile in oue or two quarters rhen he mentioned that, and so far as the sketch on the board is concerned, where we appear to ece a gun-boat shelling with rertical fire a ship broadside on to her, I think it would be quite a uselcss expenditure of porrder and ammunition. But there is one way in which I think rertical fire might possibly be of use, aud that is there a ship is running array from a superior resscl. The cannot arm all our ressels with mortars, because we expect that thes mill be running awas, but I think it is the only case in which rertical fire from one ship against another can possibly be of anj use; and the reason, I think, is when one ship is chasing another, you can get the range rery much ncarer; it does not alter very much. Wo all bnow the familiar expression that "stern chase is loug chase," and rhen one 
ressel is clasing another ther are both brought much upon the surac line. The direction does not rary wuch, but, nore important than that, the distance docs not rary so rapidly as it does in any other position that the ships may be in. I was rery much astonished to hear the lecturer mather appear to pooh-poolh the porrer of the torpedo. I think, rather, we ought to make up our minds, and I am sure we hare had quite lessons enough, that the torpedo is a rerg fearful instrument of destruction, that it is by no means such an casy thing to defend sourself against as the lecturer ecews to think. I am not alluding to what we hare heard lately in tho Danube so much as to what occurred sorne ycars ago in America. We bad ample illustration of the power of the torpedo in the American war. I am speaking mithout book, but I think there was something like thirty or forty resscls destrojed by the torpedo. I was only the other day reading a book on submarine warfare by Mr. Bames, an American, aud one ecritence cane upou me with great force. Spealing of offensire torpedoes, he said that throughout the whole of the war, events went directly to show: that in no single instance where a forpedo bont was scet to attack otlicr ressels did she mect with failure by reason of the guns of the cuemy. It was the case that in one or tro instanecs torpedo boats were badly mode, and they sank themselves. We know one submarine bout was sent out, which eank herself two or three times, and all the crew; but in no one instance was a forpcdo boat sunk by the gung of the cnemy that she ras sent to attack. That is a rery important thing. I beliere msseif, that it rould depend upon the pluck and nerro of the operator. Of course torpedo boats will only attack at night, and if we hare only the big guns of the resscls being attacked to depend upon, it is quite impossible, or, practically spealing, it is impossible, that you could sink a torpedo ressel, lowerer well you might sec her, before she got within range. All this shoms me that what we want in the nars to decide on this point really is,experience, and expcrience means mones. By crpericnee I mean cxperiments. That is a thing tre hare not had enough of, simply beciuse we are not allowed cuough noney to conduct theso experiments. If we only saw by a vast number of cxperiments what was really ranted, then we sliould be in a position to come here, as naral men, and inform MIr. Scott. Kussell and other cmincnt shipbuilders and artillerists, exactly what wo want, and I hase no doubt they would be quite able to carry out our requirements.

Commander Crpriak Brider, R.N.: I should like to saj a few mords, not rith reference to the scientific part of the questions raised by Mr. Scott Russell, but upon rlat I maj call the naral part of the questiong. I take it, and I hare no doubt many of my brother officers do, that a mau of Mr. Scott Russell's cminence and well-lnown reputation, coming here to lecture chicfly for our benefit, is a very bigh compliment to a serrice which, judging from the newspapers I hare eeen since mj return to England quito latels, has not had rery mans compliments paid to it. Great as is the adrantage that undoubtedly accrucs to the naral aud nilitary serrice frow the fact of such eminent men coming to lecture in this Institution, still there are some compensating disadrantages; and one compensating disadrantage is this, that it rers often goes abrond from this Institution that things are not groing on well in the Nars. About the Army I know nothing. What really is the casc? For instance, there was one thing which $I$ made a note of, and $I$ am quite sure nobndy will be more glad to hear it than Mr. Scott Rueecll; and that is, he spoke about the concentration of firc. MIy honourable and gallant friced Capt. I'rice spole also ubout its not being sufficiently attcuded to-about the concentration of tho fire of a single ship being in the hands of a singlo individual. Now Captain Price is a far greater authority than I can pretend to be, and he bnows, eren up to the time he last was afloat, considerable attention was being paid to it, and considerably more attention is being paid to it now; and I nean to say the Captain of a ship lias now absolute control of erery gun in the ship. Ife can direct that every gun bo laid sight a-bcam or on any bearing, and at any cleration that he desires, and he himself can fire ererg gun in his ressel simply by pressing down his little finger, he being in such a position where he can sce the encmy's ship, and where no single indiridual on boand ship except himself can ece the enemy's slip. Fot only is this the case in the Iarge ironclads, but in the gun-boat of which Mr. Scott Russcll spolic, and which he suggested should be nctually tho guu-carriage, so that the gun Ehould requiro no corriage of itself, but simply the bont in which it is embarked-that, to n's certaill 
kwowledge, has been in existenec-the system of firing the gun and directing itfor three or four years. When I was in the "Cambridge," under the commandin-chief of the Chairman, one of the lieutenants there had derised a scheme for stecring the ressel, and diresting and firing the gun by the comnumal of ono individual aborc. And that entered into one part of the regular course of instruction, and was carried out erery ciay that that gun-boat was sent to sca; that. is, at lenst, four years ago. From leading articles, rery often founded upon lectures and discussions that take place in this Institution, it often appears that cren people whose business it is to look after the service of the country do not do eo as satisfictorily as thacs might. I was reminded of this by Mr. Scott Russell's nllusion to gun-boats. Norr, I doubt whether there are lalf-u-dozen people in this theatre who can be aware of the efforts that are being made to put the country on a proper footing-with reference to the defence of its colonic3-those members of our empin: which are just as much mcmbers of our body politic az our limbs are of our orrn body-I say $I$ doubt if there are half-i-dozen peoplo in this theatre who are aware of what is being done at all erents by the present government ( 1 caunot si)eak of the last gorernment, I only speak of my erperience in the last year or two, aud 1 lasto nu ureans of information which is not open to ull the world), that thero are at least two colonies some thousands of miles apart, for which a special class of gunboats has been coustructed quite twelre months ago. And in oue colong, the land on which the stores of these gun-boats are to be deposited, mas purchased, or inade orer, by the Colonial Gorermment to the Imperial Gorernment, at all erents in 1876. So that shows that we are not quite so badly of with regard to the people at the head of the service doing their duts towards the colonies, az we are supposcd to be. I I quite agree, and no doubt mavy others will agree, with JIr. Scott llussell in his estimate of the pomer of the torpedo; and he applied a rers correct epirhet to it when he enlled it a "bugbear." I think Captain Price a little misunderstood him when ho assumed that the lecturer thought that that ressel which is shelling the large one literally upon all silies, would be destrosed by tho power of lice guns. I tale it he meant thist she was to be destrosed before sho got within range of the guns, and although those numerous losecs did actually occur in the dmericun war, still we must renember how it was that they did tale place. One oceurs to me, that of the "Tecumscl," in $\Delta$ dmiral Farragut's action at Jobile, where nearls $200 \mathrm{mcn}$ were lost. I think that is the number put down in the "butcher's bill," retumed after the action. That ressel was destrojed, as I was told, by tro American officers wloo took part in the engagenicnt, becausc the Captain of the "Iccumsch" cliose to go esactly where he was told not to, where Admiral Furrat was perfectly aware that if the ressel did go, she rould be blown up. I think that tends to corroborate the riew taken by MIr. Scott Russell of "Sarre 'im right!!"

IIajor BATIS, Q.C.: I rise to more the adjournment of this debate. Te lave lad a most interesting lecture, and we are most anxious to licar what DIr. Recd may hare to say abeut it, and therefore I think it would be mell if, at this etage, the discussion were adjourned.

The motion haring been seconded by Captain Scort, R.K., the mecting mas al. journed to Tuesday, Junc 12th.

\section{Adjodraxed Discossios.}

Tuesday, June 12th.

\section{Adyiral of timf. Fleet SIR IIENRY J. CODRINGTON, K.G.B., in the Chair.}

3Iajor LAYLIs, Q.C. : It is my privilege, Sir, or rather mJ duty, to spcak first, on oule of the most importaut subjects conuceted with the varal suprennes of Great Britain, riz., the best slips to be built, and econdly the best mode of destroging the best ships of the cnemy; and I feel naturally difficlent, amongst so many distinguished scicntific pereons and naral and military oflicers, in saying a word on the subject. On 
Friday last I came bere as a listencr, but I was so delighted with the lccture which was read and illustrated by MIr. Scott Russell, that seciug so short a time was then left for that which is most important, the discussion on the lecture, I mored the adjournment. With reference to torpedocs, I think Mr. Scott-Russell will admit that thes are rery dangerous inplements of warfare, and that we must take great care that they do not run against our best ships, and we must take the best means of running them against our eneny's ships. Ife said he considered they were rather a scare, that is that it only required rigilanee to get out of their way, but still they are (as is admitted by all) a most formidable means of destruction to the largest and best found ressels that ercr sailed on the ocenn; that being the case, I aun afraid there will be found persons minh enough to take command of a torpedo ship if there is an object to accomplish. By jour indulgence I will now also renture to mention a ferr topies which occirr to me. The subject of gun-boats has been to myeclf a matter of rery deep interest for many jears. I recollect rery mell when MIr. Laird built somo gun-boats for the Dutch Gorernment, usefil boats in shallow waters, boats that could not be approached, and could casily run out of shallow harbours, and boats that were a rery great protection to the coast, probably mach more so than those batterics which hare not the power of locomotion-it always scemed to me that gun-bonts were what we ought to have. T' rentured then to consider that they wero indispensable, or would become so, and still think so. Now wo hare heard from our able lecturer that he recommends gun-boats, and he recommends that there should be two guns, one at each end; and that there should be large resscls which should be specelier, should hare stronger bows, be handier, and also capable of endurance. He has suggested to us that the more endurance a ressel has, in other words the more fuel sle can carry, the longer she can last out, the more ehe can plas with the cnemy. With regard to the gun-boats he has made an escellent suggestion that re should hare gun-boats in different parts of our colonies arailable for the protection of their consts, and reads to assist the larger ressels when they go there. There is a curious fact which has happenced, and which will be no doubt the subject of discussion in this institution, that although in the first instance the Russians were sucessful off Ibraila against the Turkish inonitor on Saturday last, they made, it is stated in the newspapers, a similar attempt with sir launches, aud wero not successful, by reason it is said of the adrice giren by Hobart P'asha in placing boats with chains round the monitors. I would draw jour attention to one fact, that although the attack was repulscd, one resscl did, I understand, etrike the wonitor, but not in a rital part. It comes, therefore, to this, that it will require, in addition to the rarious oncrous dutics of the commander of a ressel, a further increased rigilance to encounter this eecret $f_{\mathfrak{O}}-\mathrm{a}$ foe the worst of all he can cncounter. I know the heart of a British Eailor exists in a British commauder, that he would fight an enemy openly, ho cares not whether he takes his ship against $n$ fortification or against 2 Ehip doublo his size, but what he does fear is the torpedo, and, therefore, the subject of the torpedo, and the way to aroid then, is one of the most important questions of the das in connection with the subject matter of this lecture, "The development of our IIolern War Flect." We had a lecture lately from Mr. Donaldson on that subject, and I sce also that the subject announced by this institution for the next Niaral Prize Essay is one analogous to the prescut, riz. "Grcat Britain's IIaritime lower, hom best dereloped as regards-lst, fighting ships -2nd, protection of commerce-3rd, nasal rolunteers, or supplemental force-1th, colonial and home defence; the classes of armament, and description of the resscls needed, and the organisation required to secure a powerful and economic Imperial Naral Force." Haring made these remarks, I hope that I shall hare accomplished my object by a rcrival of this important discussion, though $I$ am afraid sou will consider I was rather rash in coming forward as $I$ did in the presence of Eo many distinguished officers and men of science, but whion we nom hope to hear.

11r. Jonx A. IFelcm (Naral Architect to the Colonial Department): I slould be rery glad to make an obsersation or two on the subject of gun-boats. It may not be uninteresting to this mecting to know what las been done by foreign navies with regard to the supplying themselres with heary-armed gun-boats. I will first allude to two small twin-scres gun-boats that were built to a Chineso order in 1875. They were ressels, improvements on the steam-lanuch class which hare been 
in use in our nary, and to make them vetter sea-going boats thes mero construcled 87 feet long and 26 feet beam-2j3 tons O. JI. - drawing 6 feet of wnter when fully losded. They were armed each with a steel gun of 16 tons, 10-inch bore, and threw the same weight of projectilo as wo throw with our 18-ton gun. These littlo boats were tried under steam, and dereloped 200 indicated horse-porrer, attaining 8t knots. Thes were rcmarkably hands, making thcir half-circlo in less than $n$ minutc, which is remarkably good. Those boats were to be sent to China, but the guns wero not sent in them. They had their carringes and slides and 300 rounds of annunition. preferring to mate up the weight which could be carried, with coal. They proceded on their rojnge under sail and steain, and, without stopping on the was, they arsired with great suceess at their destination, haring been narigated by officers of our own serrice. Theso were the first small resels of that type that had crossed the sea, or bad made such a journcy. The nert class is a larger cliss of ressel, built to the order of the Argentine Goremment. Four of them were built in this countrs. They were 105 feet long, ond 30 fect bean, 416 builder's tons, with a dranght of mater of 7 feet 6 inches when fully cquipped. These were the first ressels built to take a 26 ! -ton gun. They were also tried under steam, and raalised $9+$ knots with 100 indieated horse-power, and also prored remarkably lands-that was their best feature. There was a stipulatiou that thero should be so many rouuds fired off from the heary guns, and sis. rounds were fired at sea. The ressels stood the test remarbably mell, not the least clamage being done; a point on which somo doubts hid been entertained. They proceeded under sail and steam, and arrired at their destination, liuenos Arres, harigg starterl from here in January, 18i6. I mention that to show that small ressels, hearily armed, hare been built for forcign gorernments, and hare arrired safels in a forcinn country, showing that they must, to somo extent, havo been sea boats, although not of the best typo possible. But, taking tho whole of the circumstances into mind, they were remarkuble for their landiness, for the porrer of rorking and fighting heary guns, retaining the original idea, I think, of making the resscl rirtually the gun-carriage. The broader the bost was, the steadier she became, and altogether I considier they were a great success. I also wish to show what has been done in that respect since gunboats were introduced into the nary of the steam-launch class ten years ago, and also the "Alpha," "Beta," "Camma," and "Delta" gun-boats lately built for tho Chinese Gorernment that we hare heard so much about sinco last January. I have lad great pleasure in listening to the paper, and thongh it is almost presumptuous in me to offer any obserrations, still $I$ think that in a great many respects me hare fulfilled MIr. Scott Russell's ideas, although some of the ideas haro sel to be fulfilled by a ressel, I beliere, that has no' - yet been designed. Ir. Scott hussell stated that he would like to hare a 15-inch naral gun 15 feet long. Fou will observe we hare already fitted 10.incl guns and 11 -inch guns in the small gun-boats I hare described. Ho would then make those gun-boats strong in tho borr, so as to be practically a bow of armour. With regard to that, special care mas taten in the ressels for the Argentino Gorernment. Tho gun ras a disappearing gun, and of course it had to firc orer a part cut aray to allow the depression to be obtitined. That was made of thici plate; and this expedient was adopted: that whercas the beams would hare the cdge strips under, as a usual rule, thes had then on top, and of an extra width for increased strength. Wo doubled the beams under it, and between those beams and under them fitted a strong iron girder, so that should those ressels be used as rams thes mould gire a good account of themeclrcs. JIr. Scott Russell mentioned that there should be no mesns of adjusting these resscls exeept by the officer in command, who should be able to do so by the rudder alone. That point was also carricd out. The oflicer in command c.suld go under shelter. A corering housc was built, fitted entirely for the purpose of manceurring tbo ressel, so that ererything was done under corer.

MIr. Scorr Rossele: Fou mean the gun is manocurred by the rudder.

Ir. Wezsi: Tho gun itself is not touched; we nanecurro the ressel in order to get the training, we make the ressel the gun-carriago generally. So that that suggestion has been carricd out. Mrr. Scott Russell also alluded to the ono big boro gun in the bow, and said that the ressel must be londice than any bont in tho serrice. I beliere that adrantage ras also clainacd for these ressels. Their handi- 
ness mas remarkable. On onc occasion we had the Director of Naral Ordnance on board, and Itc expressed himself delighted in that respect. Ho took comnand, and said "I mant to strilic a certain object," and ho saw in what way tho ressel would be obedient to his wiil. I fulls agrec with JIr. Scolt Russell that in some respects wo hare nut paid as much attention to these gun-boats as we liare to the larger ships. Ifo alluded to a duplicate-gun gun-boat-so $I$ understood it-that is with one gun in the bow and one in the stern, exactly the same size, and the boat to go as fast astern as ahead. Nom, if Mr. Russell ueant a padule resscl, his paddles would be too much esposcd to think of haring a paddle-whecl ressel to do his serrice; and with regard to serews, it would bo impossible to get serer ressels that would be able to go astern as fast as to go aheid; so that MIraScott Russell must hare a new design in his mind in making that obserration. I quite agree with him that tro kinds of resscls are required for tho Rogal Narg. We want to have fast vesscls to tale up a position; and we want also landy ressels, so that with two classes of gun-boats we should bo mell suited in that respect for all the serrice that mas be required of such ressels, und I hope and trust that out of this discussion that conclusion may be arrired at.

Adniml Sir Spescer Ronnsos: I rerret rery much the absence of JIr. Rced,' as I ehould hare liked extremely to hare listened to nuy obserrations which he might hare made on a subject which, I know, has uccupicd a great deal of his attcntion, and if he hat been hero and had been disposed to speal upon the matter, I slould not bare rentured to offer any remarks mjsclf, notwithstanding the great interest I feel on the subject. I hare alrays been in all these matters much more of a learner than a teacher, and I confess that from no one hare I learnt more than I hare from MIr. Scott Russcll. I bad the misforlune of not being able to be here when his paper was read, and I do not feel in any way qualifed to criticisc ans of the remarks he has made. I should only wish, from the little knowledge I liare, to supplement in a fert rords scme of the obscrtations which to made, as I fecl perfectly certain that though I did not hear all that be said, the general tenor and substance of his remarks has been known to me for screral sears. HI always has started with this one remarkable assertion or proposition, that, if what naral officers want to condluct a naral action, is knomn to the naral architect, the naral architect can inrariably supply them therewith. In that proposition I nced not say I must entirely agree, and it is especially with a rier of explaining or throwing eome little light upou the mants, as I congider them, of naral officers, in carriug out a naral action, and of what should constitute the nary of this country for carrying out a maritiuc war, that I renture to speak a few words. What I think, what I know Mr. Scott Russell thinks, and $I$ haro seldom beard any thoughtful man express any other opinion, is thi3 : Great Britain, to carry on a maritime war, not only mants single ships, but she wants a flect, and the construction of the flect is the great object that the naral administration of this country ought to hare in riew, and this principle I hope then all th sso who wish well to their country, or can influence its naral administration in the right way, will take also into their most serious consideration. A single ship, howerer perfect, let it be the "Inflexible" or Iet it be the smallest gun-boat of the $d$ lpha class, any single ship cannot in any way whaterer represent the nccessities of this country in uaral marfare, nor can it represcut the reapon mhich a naral offecr on general scrice will hare to uso in destr.ying those ships of the enemy it may be his duty to destroy, or in making those attacks upon an cocms's flcets, fortresses, or positions, which it mas be his duty to make. The countrs wants ships which shall in their rarious ways perform those services of assault and defence through which a naral warfare must be carricd on. When I come to rellect upon how naral warfare is to be carricd on by this countrs, I admit the subject is so large, the !eatures are so cnormous, and present so many sides and? difficulties, that nithin the limited time allowed for any one of us to speat in this Institution, or indeed in any rerbal discussion what soerer, whererer it may take place, 1 think it rould be utterly impossiblo to exhaust the fubject, to suggest erergthing that should be suggested, aud to meet all the arguments against such

1 Mr. Recd, oming to a prerious engagement, was unable to atlend on the day fised for the Adjourned Discussion. - El. 
and such propositions, which mould naturally occur to thoso rho licard the subject, aud whose nimls were fixed solely or particularly on some of the necessary pounts of naral warfare. But wo should all agree in this, that a flect is, in fact, what re waut; that a flect must bo composed of ship 3 of rarious clasaes; that no single ship alone will be adopted for naral warfare under tho cireumstances of the derelopment of science, aud tho mesns of destruction that now erist, and that every ship must act in combination with other ships; sho must be the unit round which otler ships congregate, and when we hare got the ship and her satellites in attendance upon her, of the right sise, sort, and stamp, then we haro got the ono unit of foree capable of doing its duts in what may be called singlo action. But $I$ think if sou cannot admit so much as that, jou must at least admit this, you must say that the whole flect of Great Britain must be so constructed, that each unit of its force sliall be composcd of ships of rarious classcs, attended by others, larger or smaller, as the case may bc, and that the concentmition of these ships and their atterdant satellites will alone constitute a fect calculated to destroy angthing that may come upon the surface of the sea. It must be remembered that the mhole object of naral war for Great Britain is not, for instance, to go to anchor in a rirer or a bay and there remain, crposed to the attack of torpedoes and of clectric mines, and rarious of her destructire agencies, though that is one portion of the duty the British Alect may hare to perform, and we know the means emplosed for destruction in the casc of a ship at a achor aro extremely formidable, and can only bo net by an equally formidablo use of tho samo sort of attacking forco as tho ship is exposed to. No one can doubt, for one singlo moment, that when large ships are compelled to anchor in roaditeads, or rirers, or narrow waters, they must be ittended by resscis of the Thoruycroft tJpe, we will sas, or of any tJpe that will bar the adrance of the insidlious torpedo, whether of the Whitelead or ordinasy tJpe, or any other engine of destruction that acts at 2 distance orer or under water, and be ready to destroj: them; while the large ship will be there to protect and co-operate with her satellites to orcreome the serious opposition of batteries and hearily armed ships, to aid in a landing, of to prerent the assemblage of troops, destincd, perbaps, to threaten our rarious posscssions. I said it ras impossible to discuss how naral warfare should bo carried on within tho limits of any epcech that ans man could make, or cren within tho linits of a rery long lecture, and I hare crnerienced gratefully the paticnce and temper with which this audience will almajs listen to remarks upon the subject, but I haro some sort of conscience, and I cannot for ono moment thinl of inflicting upon this distinguished audience the rery many important remarks that occur to me, as to the way in which this uaral warfare must be carricd on. I hare only indicated, in support of tho rery able lecture JIr. Scott Russell his gircn us, hoir necessary for our purposo it is that we should liare not single slipi, no: ironchads, nor gun-boats only, nor unarmed ships only, but that we want a thorough and comprehensire nary or flect; but as to the parts of that nary and the detrils of the ship composing it, I really rould not troub!n this meeting with saying what they shouli be. As a general schemo thero must, no doubt, be large and small ships, swift and hearily armed ressels must act in combination with others of dificrent types, to secure the duc exceution of such eerrices as are rital to our interrsts as a nation. I certainly cannot orerlook this fact. Supposing this country is cngagel in a naral karfarc, and expeditions are about to learo foreiga parts which I will not mention. I will not say anything which could bo construed into an offensiro remark with regard to any forcign porer, but we will suppose that it suited some naral poxer to make an attack upon any of our dependencics; that attack must be frustrated, and can bo only frustrated by haring ships that can be at eca, remain in the track of thoso ships that mas be entrusted with that expedition, and through the porrer of our gun, the weight of ous armour ships, the specd and coal-carrying poxer of theso large monsters which are so expensire, and which may be destrojed easily, our flect must hare the power to remain in those scas mhere you may want to fight, where the very existence of this country mas have to be decided, and where wo may find it necessary, in certain latitudes and. longitudes, to repeat, with different reapons, indecd, but with tho same results, the glorious actions of the past. For this purpose, your big ships, heavily armoured ship:s, swift ships, ships of grcat coal-carying power, are as much or more ranted than your 
gun-bost 3 or torpedo ressels. It is therefore only the simplest idea of not throwing all rour cgez into oue basket that makes me eas: Stand by a flect, and do not be satisffed with singlo elips, however perfect. Let that leet be tho point to whicl jou will gather up all your strength to fight that battle which will decide, perlisps, national existence; but for a thousand other purposes you mill want all the small ressels, all the swift launches, crergthing that has been deserjbed. It has been sometimes said that the whole nary of Great Britain ought to consist of gun-boats, or torpedo boats, or thing 3 of that binct. I am sure this mecting are much too intelligent to approre of such a course, but I hare often, in the course of my official life, found that things, reiterated and stated again and again in the columns of a newspaper, weigh upon the minds of those who have to decide how the nary shall be constituted, and how naral warfare ought to be carried on. I say it is absolutely indispensable for this country not to bo led aray by the false thcorics that are continually put before it, but to maintain a flect composed of large and small ships, porrcrful and swift ships, and others whose whole power and object should be simply to make a dash with a mine to explode it under tho bow or stern of a ship. I do not know whetber I hare correctly followed what JIr. Scott Russell has said, but as I said before, I hare so often heard him urge this point with intelligence, argument, and wit, that $I$ do not think I can hare mistaken him. I conceire it is sonnd in principle, and rithout in the lcast pledging mysclf, or any body who bas to act in this matter, to the details MIr. Scott Russell thinks it necessary to establish, in order to obtain what both of us aim at-a powerful flect, I am certain I an not ruming counter to what jour lecturer has said to you, but am rather supporting his riews, and also that thoso views are sound, and will recommend themsclres to the sentiments and to the opinions of all who haro done me the honour of listening to me on this occasion.

Mlr. Srisurva Lscos: This being a scientific mecting, I wish to put msself in order by atating that sir years ago, while sitting nest to tho Chairman, I whispered in the ear of Sir George Sartorius that science lad got command of the ship, and that practice and common sense rero driren before the mast. I know little of science, but. I wish to illustrate, by what has come under my omn obscration, what it is that $I$ meant by ecience ruming ahead of and taking the precedenco of practice. When I was in the Baltic I trice passed through the Russian flect of thirty-three pennants (great and small), which were about to be revierred by the Emperor on the same day, whom we afterwards met in his magnificent jacht coming from Cronstadt.

When we mere three miles from the flect we mere orertaken by a first-class frigate steaming at full spced, with her anchor still hanging from the bows, not fished, not catted, and I ast what mould hare been thouglit of this in the old dass of puro seamanship? The North German offers, with whom I had a good deal of conrersation, apprecinted this fact, as I trust it will bo appreciated by our own naral men.

Captain R. A. E. Scotr, R.N.: Mr. Scott Russell's rery admirable paper hav more distinctly brought before us than las jet been done, the necessity for a lirge ocean flect; a flect which will maintain our empiro on the sea, will kcep our counmercial ships free from the attack of the enemy, a.d whose duty will of course be to destroy that cnemy. Without her commerce, Fingland would be entirely crippled; her commerce is in fact her legs and her body, and it is for the protection of that commerce that re must bare a powerful fleet. I think Mr. Scott Russell has done well in scparating the occan fleet from the insbore lotilla for the protection of our orn coasts and for those of our colonicz; erery day the distinction betreen these tro tects is becoming more decided, and erery change which is nom taking place is tending greatly to our adrantage. With respect to our iron-elads and large cruisers; it would be a rery great mistake to place such raluable ships under batteries, for there is almost a certainty that they would bo blown up; as their thin decks would bo rery soon driren in by the plunging fire of large guns. I think this would bo a contest in which there would bo rerg littlo honour to be reaped, in return for the rery great deal of danger incurred; in fact more than one ressel might thus be lost without producing any result. Some of you, I daresa,, remember the attack made by our rooden war ehips on the forts of Sebastopol. It wns rers good 
jerhaps as sbowing what our sailors merc ready to do, but what was the result? Our ressels could really do nothing then, but in the present day, ngainst batteries armed with powerful shell guns, our ressels would hare no chance of eucecss. England, as regards torpedoes, has really pushed forwand the inrention of the fish torpedo more than ans other porrer, and in the use of gun cotton she has found the means of protecting her rast shores with certaints. Ifappily there ape on our orn coasts $n$ number of intrepicl sailors almass at hand, aud quite capable of haudlin thesc dangerous weapons. To do-so with success, requires the skill, dash, and coolness, which are the rery characteristics of our race, or, at any rate, they were the characteristics of the old Norse kings from whom we are in part at least descended. We hare therefore developed the rers weapons that could be emplojed with the greatest adrantage, and would fully bring out all the shill and pluck of our fishermen, sailors, and cosst population. Theso men, armed with a $\mathrm{few}^{*}$ torpedoes, would rerr soon be enabled to gire a gool account of nuy ressels that might approach near cnough to bombard our shores. A successful attack would bo practically impossible were our rery lagge fotilla of tugs and river steamers capable of acting as rams, forpedoc, or gun ressels, to be organiscd. Now that organization docs not crist, and the only thing that docs erist for our defenco is the coast artillery brigade, which is not in connection with the coastguard crews and their stations, or with the Coast Yolunteers; nor are there any telegraphic communications between the coastguard stations, or with head-quarters. If the chemy wero on the const to-morrow I do not know whose duty it would be to $\mathrm{kccp}$ hin from landing. It would doubtless be somebody's duty to fight him after ho had landed; to but in the organisation for beeping the enemy off our shores re really secus harc made no progress. I remark has been nade about the discussious in this Institution getting abroat, and other vations becoming anare of our defects. In reply I rould say that thes know them far better than we ourselses do, for we takc the greatest possible care to show all noreltics in our docksards and arsenals to forcigners, thus enabling them to comparo the se improrements with their own. If I wanted to know the defects of England's ressels I slould go on bonal a German, or somo other foreign ressel, to ascertain them by comparison. I will gire an illustration of my neaning. Inoking orer a German resscl at Portsmouth, in company with her commander, I went into the question of her armament and its preserration from deterioration, a subject in which her men as mell as offecrs took the greatest interest. I azked the commander how ho managed to heep his gun gear in such capital order, and in reply he said that he cleaned his gun deck with marn yatcr and was carcful to kecp it dry and to sce if the working gear underneat $h_{1}$ the gruns was in good order, and I found no rust whaterer upon them. I could not but contrnst this with what I saw on board our own war ships-whero the men were scrubbing away with sand and water, corcring the gun carriages with these and destroying the gear of the slides; in addition to which there wero men polishing their cutlasses with brickdust, to the detrimert of the gun carriages and gear upon which the cutliss points merc rested. Another instance of our backwardncss iras giren to some of us who had the pleasure of listcuing to MIr. Donuld Currie's admirable lecture rhen lie shored that thero vere no telegraph lines to the Capo; and eaid, it was not dispatch basts that wo manted, but 1.ther a telegraph, nhich could send information a great deal quicker. IIe storred also tbat although wo had some rery large iron-elads, still if they got disabled at long distanees from Fingland there were no means of docking and repairing them. This scrious defect has since Mr. D. Curric's statement here, receired much attention. I dare sar some of you remember that more than a jear sinec a Gorernment oficial said in this Institution that the merchant nary was of no use for purposes of warfare-an opinion which being dissented from was nfterwards rery much qualificd. Subsequently wo lieard that the buring up of the fastest steamers of our mercliant flect would at once enable crery port of an cremy to be effectually closed. Thiat was however going to the opposite estreme. Hut the wise course is, take the merchant nary as it now exists, and for new ships, to use erery elfort to obtain ndditional strengthening bulkhead, and those water-tight dirisions that many of us think are as raluable in merchantmen as ther are essential in war ships. JIr. Scott Russell, in asking for discussion upon lis proposcd ccllular construction, may rot. XXI. 
say, if uaral men will only point out what is required, that then it is sure to be carricd out; but I replr, naral men harc continued to insist that the first point to be considered in a slip is unsinkability, and consequently her bottem muzt be dirided into numerous ecllular spaces. The torpedo lias done much to effect this result, but as yon already know, the "fish" is a dlingerous reapon to those who uso it, howerer skilfully it may bo handled. 'The fish torpedo will run about 250 sards st $\mathbf{2 5}$ knots, but if required to run a longer distance, it must go at a punch sloser rate. It is propelled tbrough the water by double compensating cngines. norked by highly compressed air, and though the Iecturer does not consider it a rery formidable weapon for ocean warfare, it will run about a thousand jards at a slon specd. It the end of eeren or eight liundred jards, lowerer, it conmences to direrge from a direct line. I think there is a source of danger in the way in which thoso torpedoes are (as I an informed) straightened when they are a little out of truth, as there is a tendeney in metal to return, after a time, to its original shape. I think, therefore, it will be found that torpedoes which do not go aceurately when first tried in the canal, and hare to be straightencel, will, after being scme time on board ship, resume their original curred running on being discbarged.

Besides the fish torpedo, there is the spar torpedo, which from its simplicity and the largo chargo it cau carry, is a rery raluable ireapon for general use.

Our merchant shipping carry at the present time some capital life boats, and any of these, or the lighter gigs, could take one of thicso spar torpedoes, and if the fellows had coolness and pluck, and their ships fired of a little porder to mask the dircetion in which they rere going, there is no doubt that tho boat might dish in and, as a rule, gire a rery gcod account of their enemy. As bearing on this point, I may tcll jou of an attack upon the "Excellent" just as it was told me. Captain Singer was in command of the party on board, and one of the gunnery offecrs, the commander, I think, of tho "Vernon," was leading the attacking party, using the spar torpedo. The crew on board watched and waited, keeping the strictest look out, having boats patrolling all round their ship; theso bonts pulled backwards and forwards and continually spoke cach other. The wird was from the "EIcel'cnt." The skiliul oflicer in command of the attacking parts looked out for his opportunity, and after a time got to know exactly when the patrolling boats neared cach other, and then, seizing his opportunity, he dasled formard, rin his boat past the patrols and struck the "Ercellent" fairly before any of the defending party could cut hin off. In this ease there was the guunery ship herself watched in every way, and yet with her stilled crew and all her applianecs she could not prerent the spar torpedo from being run ngainst her. If a ressel so ready could not prevent this, what fate might be anticipated for the ironclad that foolishly rentured closo to a guarded shore or came near an enemy's port? We must, in my opinion, no longer thinl of taking ironclads into narron waters; the time for this, I think, has altogether passed.

There is another weapon which I beliere there will be an opportunity in this thcatre of your sloortls bearing something about, namely, the rocket. I will only say that this rocket can bo made to go under water, carrying at least as large a cliarge as that of the fish torpedo, orer mhich it rould hare the adrantage in cost and in simplicity, and it can be casily carricd in any resscl with comparatire safets. Before addressing myzelf to the details of Mr. Scott Russcll's plans, I wish to add that I hare hnown a great many good effects to result from our discussions here. I do not quite like to mentiou the instance, although some hare resulted in raluablo modifications of rarious ships and their armaments. I renture to recall to your mind that the I) ube of Somerset and others of our highest oflicials hare spolen very strongly of the ralue of this lnstitution, as affording a mcans of examining and discussing important inrentions, \&c., and thus enabling our Statesmen to male usc of the information for the public bencfit. This benefit ras apparent in the case of the gms with which we were going to arm our nary eomo sears since; I allude to the brecel-loading guns. There mas a lecture giren here, followed by a discussion, the Duke of Somerset being in the chair. It ras said by those who supportcd the brecch-loader, that all the yary wantcd in addition to the brcech-loader was a gun or two that mould penetrate armour plates. If you turn back to the discussion on the subject, you will find that. it was strongly urged that the Armament of the Fiery should mainly conisist of guns 
nowe powerful than the breech-loalers, nnd a short time afterward the 100-pounder smooth bore guns were adopted, and subsequently heary rifed guns, muzzle loading; and to the Duke of somerset we are greatly indebted for the improred iron gun carriages now on board our ressels, carriages which hare been, I belicre, copicd by all other nations. I great deal has been said about the superiority of our guns. Now in Clina the other day, as I was told, the French admiral said to the English admiral, "Fou think your guns are better than mine, cone to sís with me for a couple of days." Our adniral replicd that he would go with pleasure if he might take his gunnery lieutenant. This being agreed to, he was on the French ship during her tro dars' firing and exercising. The guns were fired at from two to four thousand yards with the greatest accuracy; and I suspect that on his return our admiral mado rather a strong report on this subject. is the costly armour of our ironclads is put on to withstand an enerny's guns, we on our side ought to bare the rery best reapons we can get, so as to destroy his urmour and sink him ns $800 \mathrm{n}$ as possible. With regard to tho 36-ton gun which Scott Russcll adrocates, we have heard that a number of gun-boats hare been built lately, each to carry three 61-pounders. I do not know what stations those gun-boats are intended for, but tho Chinese hare the "Alpha," "Betr," "Gamma," "Delta," armed with 3S-ton guns, and therefore capable of opposing any ironclads that might come to attack their ports. Ilow we are mith our lightly-arned gun-boats to beat off heary war ships, I cannot quite sec. With respect to DIr. Scott Russell's node of mounting his.standard 36 -ton gun and making the ressel the means of pointing it, I feel quite sure he makes a greal mistake. I hise tricd to point guns by means of the helm, but alwass found that just as the man was going to fire, the ship gave either a slight roll or lurch, or elso a swing, and disturbed the aim. To point and fro a gun fixed in the bow, she must keep udrancing, otherwise she cannot fro. To remedy this defect in part our 18-ton gun-boats ure arranged to gire their guns 25 degrees of training on each bow, but that is not cnough, because the gun-boat can only fire when it is approaching an cneng. What fou should do is to malio any new gunbouts a littlo larger, so a3 to admit of their heary ordnance being given a wide are of training, using applianecs as simple as possible. I quite concur with what MIr. Scott Russell sajs as to simplicity, and I think $I$ can illustrate its ralue and show that I hare not becu wrong in asserting that all our guns ought to be worked on one uriform system and by the sinplest machinery. Wo can work guns up to $\mathrm{ffty}$ tons reight by liand appliances, but I do not think ro can go bejond that with adrantage; in fact I think properly rifled 40 -ton guns would be fully equal to dọing our naral work. 'The 38-ton ship guns are nor being worked by hydraulic machinery alone; although thero certainly has becn some attempt to work them also by hand. "In the "Thundercr's" after-turret thero aro tro 35-ton guns mounted and rorked on the hand-machinery principle, which would nerer hare been carried out but for the support of the former Controller of the Narg. In the foremost turret are two 38 -ton guns, but if anything happens to thcir machiners the crew rrould hare to get outside the turret to load. IIow the different operations are to be efficiently performed in action, should the hedraulic machivers get out of order, I cannot tell. You may homerer eay that the hydraulie nachiacry will not get out of order; possibly not. There irss a great hurry a little more than a fortnight since to get the $80-10 n$ gun to Shoeburguess. There it lay on tho Arsenal wharf, and thero mas the magnificent 100-ton hisdraulic crane readj to lift it, but unfortunatcly the crane would not more. With all the talent of the drsenal, for four days nobody could discorer what was the matter, so tho gin las a fortnight before it was lifted from the rharf into the barge alongsidc. That little incident shows how dangerous it is to trust mainly to gcar in which the failure of a ralre will at once place the gun hors de combat.

Mrr. Scott Russell says he wishes to hare crersthing as simple as possible, yct that he will muzzle-pirot his proposed 36-ton gun. To muzzle-pirot you haso to lift the whole weight of the gun by the breech. Has MIr. Scott Russcll considercd the enormous power that is needed to lift continuously and rapidly through smill epaces a 36-ton gun; does he know that it would take a height of 14 fect to gire the nsul cleration and depression with the 36 -ton gun, and if the slightest thing gocs wrong vith this elevating gear he could not use his gun at all; but supposing the gun to 3 c 2 
get a hears sbot in the muzzle, then in all probability the coneussion would break tho lifting gear, and the breech of the gun rould fall down. MIr. Scott Russell sass that he would make the ship the gun carriage, and would keep broadside guns pointed abeam ; but just as the enemy was passing abeam, there might be no opportunity to fire, cither your friend might be in the way, or your oyn ressel might sheer off a little and disturb the aim. You would not hare nearls enough training in these narrow casemates. Fou would also lose the opportunity of firing to the best adrantage in a sea way. If you can train your gun so as to be able to point forward or aft, you would be cnabled to place your ship so as to be tolerably steady instend of haring to fight when rolling herrily in the trough of the sea. Mir. Scott Kussell appears to hare some doubt on this point; but how does Mrr. Scott. Russell propose to arm his cruisers? IIe intends to hare a bulkhead forward and another bullhead aft, so that the crew would hare no protection abeam. I think eren on his own showing this arrangement is wrong. Mr. Scott Russell speaks also of haring lighter guns to fire only ahesd. I think, ns a geacral rule, that a ship adrancing to ram would not fire; the time she would firc her guns would be after having attempted to ram, perlaps while rubbing along the side of her enemr. I doubt rery much the value of letting of broadside gums by elcetricity, for I think jou are scry likels to fire all your broadsido guns at the wrong moment. I hare contersed with a great many practical men on this subject, and I bave considered the question carefully myeelf, and so far as $I$ can gather, when good practice is made is, when a good captain of a gun is looking along one of the centre guns; but when the captain of the ship placed abore the battery gires the simnal, he is rery likely to mistake the time of tho ship's rolling, and to miss with crery one of his guns. With respect to $\mathrm{MIr}$. Scott Russell's mode of plating, souse of jou who haro ratehed the recent experiments at Shocburgness hare long known that our cast-iron projectiles gencrally crnck, or break up on impact. Recent crperiment has shown to what this is duc; when the shot is cast in sand, the liead is crst in an iron mould and chilled, consequently its particles arc in a rery strained condition. Hence, recently, in passing through a 4-inch plate, the projectile broke up; falling against a 10 -inch plate it failed to penetrate. This projectile rould, under ordinary circumstances, hare penetrated not only a 1 -inch plate, but a second, third, and fourth 4 -inch plate if teak had been interposed betwecn tho plates, because the rood would hare absorbed the ribration, and placed the shot in $n$ condition to penctrate the nest plate. There scems no doubt that the sliot aro destrored br ribrators reaction from blors, and Captain - Grenfell recently brought to notice the fact that when steel plates were fired at at Spezzia they did not crack at first, but a singing noise was heard, and soon afterwards the plates eracked from the ribration. The hardness of tho steel secmed at once to stop the projectile, and the tremendous blow broke it up entircls. There is a very raluable principle ehewn by this experiment, riz., that if we have a strong plate, say four or cren two inches thick, it mill crack the cast shot, and then if wo ndd an inner plate of eight inches thick, and place it at four or fire fect on the insicle, it will stop the shot altogether; and mith this distance betrcen the inner and outer armour plate, you might hare a torpedo striki... the outer part, and exploding upwards betwcen the plates, and do no more injurs. That is ono possibility of using armour in the future; and it secms lo me that if wo cannot do something towarts the improrement of the system of putting on armour, we should not go on building large ironchds which aro so difficult to keep at sea, and so erecssirely costly in their repair.

Captain Gandixer, R.F.: I should like to ask Mr. Scott Russell if he will bindl! tell us how he proposes to girc light and rentilation to his cascmatcs.

Captain J. C. R. Coross, R.M.d.: I wish to make a fer short rewarks. With regard to the casculates, I presume, though cach of them has a magnzine belonging to the gun, below, they are not sufficienlly strong to resist an explosion of that magazine. There is no doubt about the cascmate principle, but it is a matter of detail that in multiplying the number of your magazines you multiply sour danger, and render necessars an increase of jour complement by as many magazine, crens as you hare got guns. IIr. Scott Russell laid domn four qualifications as neccisary to win-specticr, landicr, stronger bowed, and more gun poter. I mould really like to suggest that thero is possibly onc other point, and that is a-protected, pro- 
peller. I say that bccauso it is a rery gcrious thing that the fatc of a ship having so many valuable lives in it, and costing $£ 560,000$ or $£ 600,000$, shoud all bang upon a propeller, and wight, as we know, be brought up by rers small and insignificunt means. II attention was directed to this some fire jears ago in a emall steam yacht of my own, when fishing on tho West Const of Ircland., I found one night, through a bad look-out, while steaming about ten miles an hour, I was suddenly brought up short. We could not make out what it was, but in a rery few minutes I ascertained that $I$ was brought un by an old net haring got cntangled in the propeller, a net so rotten that if sou held it in your hand it would thll to pieces. I laid that fact before the Torpedo Committec, and Lord Otho Fitzgeruld, in a discussion which took place here on IIr. Thornyeroft's paper, alluded to the fact that the sinallest rope- jarus or nets would paralsse the action of your propeller. In order to support my suggestion to MIr. Scott Russell, that the protection of the screw is a rital question, 1 hare gircn a good instance connceted with peace, and now here is another that was mentioned in this Institution by Sir William IIall, in the discussion that took place ou MIr. Douald Curricis paper. "The 'Victor' ou the West Cosst of Africa was towing a collier when the serer " was fouled by tho hawser; they could not clear it, and with the assistance of "the "Bristol" it took 18 dags to clear the screw, and they drowned a direr in "doing it." So much for pesce experience. I will now tako one moro of war esperience. We hare heard a great deal about the lessons to be learnt from the Geruan war, aud we hare heard of the military arrangements which produced tho fall of Paris, and we fly away with details, and I think are a litto apt, as Sir Spencer Robinson pointed out, to forget general principles. Thero was a small naral occurrence that happened during that German mar, nowhere ncas the Coast of Europe at all. It was an action fought between a German and French gun-boat off Cuba. The French gun-boat, the "Bouret," was furnished with erergthing that Irr. Scott Russell lass down. That is, compared with it sautagonist the "Mretcor," it was speedier, handier, and had nine guws to the "Yretcor's" threc. How the action was brought about is rers instructire, and I hare not seen it mentioned in our country execpt by one magazine. It took placo just outside the neut ral waters of Cuba, aud it occurred in this was. Perhaps MIr. Scott Russcll-had this case in his mind when he drew our attention to what was likely to happen in regard to naral actions. About 1 p.m. the "Actcor" obserred the "Bouret" coming down ns hard as she could steum, and fire was opened at 2,200 sards. The "Bouret" intendal to ram the "Bleteor," and the "Ileteor" intended to ram the "Bouret," and what happened was this. Ihe "Bourct" struck the "Meteor" a little to tho port-side, and for a few minutes the two slups, as described by a Gemman writer, wero locked in a ehort crubrice. In that positiou the "Bouret" fired her broadsido guns into the "Jetcor," and I may mention the "Mretcor's" portside was store in, and that her foregard was carried airay, her mainmast eprung and her mizenmast went by tho board. They wero in this short embrace for a spice of time not long enough to board, and pasied cuch otber. "The "Bouret" tricd to turn, but the "MIctcor" managed to bring her guns to bear before she did completr's turn, and with one of her guns she planted a slicll in the boiler of the "Bourct" which inmediately put that vessel out of action, and there sho was at tho mercy of the snaller ressel. Just, however, as the sualler ressel mas going to tabo adrantage of her crippled antagonist, her own screw fouled, and sle too was utterly powerless and helpless. Now that action lastecl over two hours : it was just orer nentrality bounds, and the result of tho two hours' fight wias to place both ressels hors de combat. The lesson to be learnt from that I think is this, that had the "Mretcor" possessed a protected ecren propeller, sho most ccrtainly would hare taken the "Bouret" or sunk her, though she hind three times her gun power, with greater speed and a larger screw, and thercfore I reuture to suggest to Mir. Scott Russcll that the propelles is a question worthy of being most seriously considered. With regard to the general question, Sir Spencer Robiuson has renderch it quite unnecessary to repeat all the remarks $I$ was going to make, but I think the question of ships cannot be settled simply and cutirely as a question between naral officers and uaral constructors. I say so with all deference, and for this reason, that I think that the imperial interests that ariso from our geographical position, the strutegic arrangements of a gigantic empiro liko oura, 
dircetly influence the whole question, and that it can only bo approached first of all as a principle, as to what jou expect of your nars, and what sou require your nary to do. Once you hare that settled distinctly by the country, and by the House of Commons, I am quite suro jour naral constructors can certainls gire the empire the ships, and the implements that the naral officers require in ofder to do, not what tho country wants at the minute, but what our imperial position requires that we should do. 'The fact is, it appears to me, that the country is grossig ignorant of our imperial naral requirements, and eatches at any straw to escape from deciding what our nary will bare to do in war. I think, when the ordinary British public talks about any one of tho magnificent ships, it imagines it should be equal to each and all of theso dutics; that it should be able to attack any fort; that it should be camable of ramming ans iron-clad; that it should be able to shirmish along a rater line 15,000 miles long; that it should bo equal to kceping station off a neutral coaling port for months; that it should be capable of kecping stations at the crossings of the Equator for months; that it should be capablo of defending locally, Singapore, St. Gcorge's Sound, \&c., \&c., and the Colonies of Great Britain, which are sixty times her size; that the same ship must be cqually capable of blockading the Lwour, or blockarling the King of Dahomes, or of kceping station 3,000 miles from its coaling storcs. That is the British public's ordinary idea of a ship; and then it must, besides all this, be capable of defying torpedocs in the Danube, or at the mouths of the Nilo; I mention this because I do not think that naral oflecers and constructors are haring a fair chance. I do not think that our countrs, great as it is, at all understands what are our impcrial neccssitics with regard to our nars. The misfortunc is this, that though we are a great, and we must always bo a great naral power, wo think more of the arms than of the nars. We shall not hare the Issions of experience reaped by others in a great naral war. No great naral mar can take place without our being in it. The wars that haro recently taken place hare becn purcly military, the whole mind of this country is becoming purely military, and I do think this is a danger, because all our practical experience is gaiued from militarg warfarc. But when a grent war comes this country must sink or, surim accorling to the way in which she is prepared-not as a military nation, but as a grcat naral poner-to meet it.

Rear-Admiral Sir Jorx Coyserelz: Fou hare hend what Captain Colomb has said the nation will require us to do. All I can eay is this, whatever the nation may justly require us to do we shall endearour to do to the best of our ability. With regard to the vesscl proposed by Mr. Scott Russcll, there is one question I should like to ask him, and that is, if he proposes the guns to pirot entircly in the port, or whether he intends us to hare a certrin space in the port to enable us, when wo are not engaging the encmy at close quarters, to sce what we are about; it appcars to me that the port that he has described in the casemato will leare us almost in a stato of total darkness, and I do not think the men inside would sec what thes were doing. I beliere in action the great point is that erery offecr and erery man in the ship shall know pretty well when he will be called upon for work, and what work he will hare to do. As to the gunboats themselres being carriages for the guns, I am afraid that would not answer. In adrancing up rirers sou mould hare no doubt to engigo an enemy on tho banks, and at any attempt to iurn to port or sturboard, the current would catch the bow, and tho chances are, would take you on shore. At the same time I would infinitely sooner see the size of the gun sacrificed to a certain extent if we had a good gun carriagc, so that the gun should hare a fair angle of training. I cannot understand mreclf another point mentioned by Mr. Scott Russell, and that is that in his gun-boats he rould hare a stcrn fire as rrell as a bow fire. It appears to me that if both these guns are to be without carriages, simply pointing right abcad and astern, when fou are adrancing against jour cnemy, jou would alrajs hare one half of your armament out of usc, and if you were retreating jou would hare the other half of your armament the same. I should like to get an answie to these questions.

Commander W. Dawsox, R.N.: The mecting will, I think, scparati with some disappointment. We came here on purposo to hear naval architects dweuss some rery important points of naral architecture, and unfortunately mo havo oot been gratificd. There mere some points that I elould hare liked to haro heard aiecussed 
with reference to the shape of the proposed midship scetion, whetler it is to be a $\Gamma$, a $U$, or an $O$ ? and as to the length of the elhip, whether it is essential to go back to extreme length for a good fighting ressel? I am not going into these questions, for I want to direct attention to the offensire pomers of ebips. The purposes for which ships of war are built, are to clamage and destros by anj means hostile resscls and fortrcsses rather than themselres to merels passircly leep out destructire projectilcs. Unfortunately the various offensire pomers of ships hare not receired the same attention as their defensire resistances. MIr. Scott Russcll, in wishing to aroid the torpedo "seare," lias perhaps gone a little too far in orcrlooking the important :uriliary part the torpedo will play, offensirely and defensircly, in general actions. If Captain Bridge was present to-day, I would say to him that if the encung had ou cither qunrter two IInrver toming torpedoes, four or fire Whitelicad torpedocs on cach broadside, one or two spar.torpedoes on each bow, nnd if the hostile ironcled wis so anned in addition to her guns and to her ram, and met anotler ironclad similarls prepared for action, the ran would probably not bo brought into action at all, and the battle would be decided by artillery or torpetoes. Then mith regard to the ram, there is a very wholesome respect for the ram in the form now used in the British nary. It has had the honour of eending one of IIer 3Iajesty's ships to the bottom, and has nearly sent ecreral others to the same destination! 'The highly cffectire character of the ram as at present shaped will account for what Mr. Scoft Russcll saw at Portsmouth, narucly a sheathe to protect British ships from destruc. tion b5 British rams. But there is one point with reference to rams, on which I have a strong opinion that we are going on a wrong teck. If only one thirl of the ships of tho British nary are to bo furnished with rams, which third ought it to be? II impression is that it ought to bo the smaller veszels. Pit a ebort gun-bont like the "Brady" against a long ship like the "Northumberland," and let both stop firing and try ramming. Which of the two ressels would be more likels to ram the other? Why the short "Reads" gun-boat ought to sink the long "Northumberland," being much the liandicst ressel. If that be so, then, in my judgment, all the small ships of the nary should be armed with rans. I sce, with some little renret, a rery great friend of the nars, a rery eclebrated yachtsman, adrocating our fitting out gun-less rams. II cxperienco of exceptional ressels is that they are sure to be in the wrong place at the right time. Gunless rams will bo ent up the Baltic to attack a flect, and instend of ships they mill have stone ralls to nttack, what then will be the use of these gimless rams? What anin would be tho use of gunless rams when attacked by gunboats who ehelter themselrcs from such attacks in shallow water? What would be the use of gualess rams in attaching resscls protected by torpedoes? What superiority mould a gunless ram hare when contending against a fully gunnerl ram? I was surpriscd that so intelligent a friend of the nary, an artillerist too, should hare giren way to the torpedo scarc, so far as to hare been frightencd out of his guns. All these arms are necessary, and artillery most of all. Mr. Scott Russell has drawn attention to the offensire nnuawents being caccedingly weak in proportion to the size of our ships. We hare slips of some $\mathfrak{9}, 000$ tous displacencut, carrying onl 140 tons of ordnance. Is that llatation neccsary? We hare at ship of 11,000 tons displacement, carrging only 320 tons of ordnance. Is that floatation ncesssary? Would not such a slip be more fitted to figlit an enemy if she conld substitute for some tro or threc hundred tous of defensive armour that wcight of offensire ordnance? Afr. Scott Russell bas aleo drawn attention to the adrantage of our going back to the gosd old custom when erery ship. in the nary carried guns of rery much the eame type, capable of penetrating not only ressels of her orn size, but the eides of ans encmy, howerer large the hostile ressel might be. We hare had, in the last week, an illustration of what I two or three times pointed out in this thestre as a possible oceurrence. We haro had a British ship-one of the most splendid frigntes in existence-and a splendid corrette, sent out to the other end of the world to protect Dritish interests. These two British frigntes lave fought, not eister ships as they were designed to fight, but i wretched little Peruvian ressel of about one fourth their size, and armed with guns, I renture to say, about one-screnth the weight of those uscd by the two British ships. What is the conscquence? Wo the British ships bnock the wretehed little Perurian gun-bont into lucifer natelies? No, ther do nothing of the kind, 
and, as I barc often pointed out in this theatre, they could not do it, for the simple reason that they have been sent to the other end of the world furnished with guus which cannot perforate the armoured sides of the littlo P'eruvian. British correttes and frigates are almost inoffensire when called upon to attack armoured gun-boats like the "Huascar." I do not think that British correttes, sloops, or frigates, ouglit to be without armour-piercing guns; and without rams, so as to be placed in such a position that any rretched little ironclad shall be able to stand up against their sterns. 'The guus of wooden ships are not only too small, but we deliberately selected for the British navy that gun which we were oflicially told gires decidedly the lowest relocity, and therefore the wrakest blows. Mr. Chairman, I congratulate you, who so biudly came forward on one oecession when oecupring a rery prominent position to countenance me when I brought the weakncsses of British rifling before the naral public, and I congratulate the Royal United Serrice Institution, that happily that sjstem of low relocity rining is now a thing of the past. We shall no Ionger be able to say of British guns that they gire the meakest blors, and fire the reakest shells, and are of small enduranee. Whether the system of rilling which has replaced the French stud rilling is the proper system, is another question; but it is a matter of rers great congratulation to this Institution, after the discussions we hare had in this theatre, that at last the British authorities sec the necessity of British guns being able to fire such projectiles as will do the grentest amount of destruction to the enemy, and the lesst amount of destruction to their own guns; and that will perforate the enemy's ship. Those are the points in the offeusire ralucs of ships of war to which $I$ renture to call attention. Our time is short, and had we not becn disappointed of our naral architcet friends taking part in the discussion, I should not liare rentured to hare placed these thoughts before jou.

Mr. Tnosis JIOr, dssoc. I.N.A. First. I would epitomise the work of the last cighten Jears in the Rogal Nary in the words, "Down to the water's elge"and-"Back again," and I congratulate Mrr. Scott Russell for haring giren the final touch in bringing us back to a wholesome amount of frechoard, and, I think, the sooner those "low flat things" are improred off the face of the rater the better.

Secondly. I think that Jr. Scott Russcll is quitc right in choosing what I would call the chisel form of stem for ramuing. Wo engineers always prefer the chisel if we are going to cut into anything, and it is a far better form than the wcal underwater ram now used.

Thirdly. I would suggest that this form of ram shonld be placed at both ends of the ship.

Fourthly. This country possesses a great source of "strength" and of "wealness." Our "strength " consists in the immense amount of inrentire talent which we possess. Our wealuess consists in the persistent neglect of that inrentire talent by erery Gorernment which we hare.

Mr. Scotr Ressel: I almost. feel that my work lias been done by the many able men who hare giren this Institution and myself the great benefit of their opinion on the different points which I raised, far more for the purpose of getting their opinions than of giving out any opinions of my own. Nicrertheless I was quite willing to commit myself to some definite statenent or other, otherwise I do not think I could hare got you to come out as you hare done, and give me such precise statements; some, I thank you rers much, helping me in the points in which I am strong, and others helping me equally by showing me the points in which I was weak; I am therefore equally grateful both to those of gou who strengthen ine by strengthening my right opinions, and to those of you who strengthen mo by showing the weakness of $\mathrm{my}$ wrong opinions.

Now the Chairman was kind enough at the outset to say a word on the subject of the rentilation of the cascmates and clcration of tho gun. The strength of the cascnates was also alluded to by Lord Duusany. On the point of rentilation of casemates and the lighting of casemates, which was raiscd later in tho debate, allow mo to say that that is a scrious point to which I hare giren rery serious consideration. If you will allow me, I will not ask you to enter upon any particular plan of inine for rentilating the casemates, but I will simply venturo to say this to you, that when we get together for the purpose of doing this, I hare no doubt we shall find creellent. 
wars of doing it. I liare already quite mat tured a methol of doing if, and uniess we had thoroughly matured a method of doing it, I would not have reconmended it to sou. But 1 do not want sou to approre of any of my methods. I only want you to say this with confidence, "We will hare thesc cascmistes properly lighted, and we will have them properly rentilated, and we will lare them done in the best way we can discorer of doing them; and if JIr. Scott Russell's was happens to be better than other people's, we will take his, and if it is not, we take the other people's." I think that is a much better position for me to take with you than for me to say that "I hare a beautiful plan of rentilation-better than anybody cleo in the world, and if you will only disten to mo and nis plan of rentilation we shall be all right." I won't say that; but I think I may say to you, that if I had not thoroughly found out how I could with perfect certainty, simplicity, nnd safets, in the wirldle of a battle, secure a complete rentilation and lighting of thoso easemates, I should nererhare come here and proposed their cristence.

Next ns to the gleration of the guns, lifting the centre of the gem, and as to all those difficulties, I entirely agrce with you that all the difficultics were there, and when I came bere I had got orer them all, but I said, It will vercr to in this short. lecture to go into erery one of them. I said to mysclf, "I shall find Cuptain Scott there, and they all know that Captain Scott can urako a gun do anything be likes: and we hare only to eay to Captain Scott, 'Now, Captain Scott, this gun is to be big borc, she is to be brecch-loading and muzzle-piroting, she is to beep out the enemy's shot and shell, she is to be close, avd you are to find the way of handling her." How I come to you and say, if Captain Scott cannot do it and gires it up, then I am all ready. : That is my mode of working the guns on the pirot system. Captain Scott's first, nud when lic fails, miuc. As to the elcration of the gun, I quite agree with Captain Scott, I quite ngrec with tho Aduniral in the chair, that we must proride both for lafing the guns and for clerating them. We must do that. But I must counc back agian aud ask you seriously to consider the point I lave put, which is not my point, but tho point which most experienced officers hare put to me. I was falking in all I said to sou about liying the guns in a permonent nauner duriug that particular engagcment only of lroadside guns; nad for the purpose of handling a large ship and a powerful broadside in the dreadfully short cugagement. which will decide sinking or gaining a rictors, $I$ do not think you can leure to indiridual gunners the doing as they like at their diseretion with the guns used forbroadsidc purposcs; and therefore I think you ought to make up your mind, beforthe engagement takes place, what is to be the general lic of all tho guns, and what is to be their mode of acting together, and theu allow mo to sas I would call the cight other guns of the elip by-if you like-the old-fashioned name of "chase guns," that is to say, I proposc that crery ship of anj considerable size shall hare four bow gans and four rear guns. The rear guns are not for running away; the rear guns are for decoying your enemy to follow you into the place where you want to be followed, and taliug him into a serapo he does not understand. 'Ilat is what I put the four rear guns for, and I think they would be cxtremely useful in a serape which I necd not tell you about. Four bow guns, parallel to the kecl as a normal position, and four rcar guns parallel to the kcel as a normal position. I think these four of the greutest importance for close and distant action; and remenber that this ship of jours that we describe is not only to rum one ship, but is one of, sas ono dozen, who are rumming at least another dozen of similar shipz, and I do not think, unles 3 sou aro in a position to handlo the whole ship mith a perfect certainty that cach gun is doing what you want, that you can fight that battle and win it; but I mas bo quitc wrong.

Lord Dussang ashed whether the cascmates which I described were guarded against oblique firc. That only shows the difliculty there is in a lecture in going through the whole of an cuormous subject; but 1 think jou will see first of all, there is in the great cent ral part 26 fect width. (Sce Diagram II, which shows the fore-armoured bulkhead giving complete protection against oblique fire). Then I am here drawing you the space of the casemate, and there is eacle casemate with its oue gun. Allow me to make an cxplauation. In one part of the paper I sas, "each cascmate with two guns in it"; in another I say, "each casemate with one gun." dllow me merely to say that $i$ considered those two points rery scriously, 
and I beg you to consider them rers scriously. I haro looked into the question of haring onc gun in cach cascmate, and that lias many adrantages iu point of strength; it has also adrantages in point of eafety. Then there is another point, I think the companies of two guns will get on better if jou hare a stronger company at a gun, and two of them, because the supernumeraries can be on the one gun when ther are off the other gun. - Therefore, in the beginning of my inrestigation i arrived strongly at tho opinion that it was desiruble to make each cascunate double tho breadth, and to hase two guns ueting together in ono cascmate. I was only driren out of that by the questions of strength and safety, and coming to the question of greatest strength, with a gircn weight and the best protection with - safety, I camo then to the conclusion myself, but I do not at all say it is the right one, that it was better to hare the one gun in cach cascmatc than to hare the tiro guns in one casemate. I beg sou to ecriously consider that, because none but a practical scaman can settle that question; but I will tell jou what settled it in my own mind-the question of eccurity. The Chairman and Lord lhumsany put a rery proper question to ne, riz., as to the strength of those casemates, and whether what - I proposed to lare might not lead to a certain source of weakness. I am much obliged for those observations, because they readily lead to a scrious point. This ship is a ship we will say of 10 casemates to a side, or 15 cascmates, that is to say, sou hare a ghip of 20 or 30 broadside guns. This battery is considerably more, in erery case, than half the length of the ship; but when it comes to this end (sce Disgram II), I hare there an armour bulkhead going right across the whole cnd of the ship, and at the other cud is a similar bulkhead, so protecting the entire ship in its centre against any effect of oblique or chase fire. It is by enclosing them all within each, first, its own armour, and secondly, the two end bulkhends of armour, that I nender these casemates perfectly unassailable to obliquo fire. About the question of strength Lord Dunsauy eaid a rery wise thing: he said if these ships were made like common ehips, full of little barz of iron, which take the place of our old frames, if thes were full of these little angle iron bara, that then there rould really be no sup. port giren to the plate of armour, and that the structure of the ship and the armour plate rould not at nll aid each other in strength. That is perfectly true, nud, therefore, what I propose in this matter is simply this - the "Great Eastern" is one of the strongest of ehips, and in her sides the clements of etrength are placed at about 9 fect apart from cach other, both lengthways and rertically. Nor, here I propose that from casemate to cascmate there shall be 11 fect, and that rertically it shall be 9 fect, and, therefore, those casemates that I am showing you are exuctly the material construction of the "Grcat Eustern." This rall is nothing but a similar bulkhend this wall is nothing but the tro great longitudinal bulkheads that constitufe the strength of the "Grcat Eastern," and, therefore, the cascmate is made of nothing but the iron deck below, the iron deck abore, both of which are necessary parts of the ship; thoso cross bulkheads which are necesary parts of the ship, and go from the longitudinal bulkhead to the outside; and, therefore, six sides of the cascmates are only the eir large integral clcments of which the ship is built. Then, in order to gire these due strength, we plant on ench side of theae a single large plate of armour, which corers the whole, and which end where these porrerful buttresses begin, and, therefore, the whole foree expended on this plate is propagaterl through these to the whole bods of the ship, and each plate has as its reinforcement the whole body of the ehip; therefore there is no doubt whaterer that by that - Incthod jou can conres to the plate the mhole strength of the internal bods of the ship. I did not ehow, because it would complicate it, that the huces of the ship mould como in at each of those corncrs (Diagram II), and crcrs oue of thosc plates would bere be fitted by a great knee, and thint corner would be upheld by another great knec, and then abore and belor and up and donn there would be all theso hees coming in to support the whole of this armour plate, so that that armour plate is really in the strongest position in which it can be placed.

Captain Price said, with regard to the form of the bow; that he liked the epear. Well, I sbould think a eoldier would like the spear, aud equally the gentleman rho was an engineer said le preferred the chisel to the spear. With respect to ramming tho elip, Captain Price olso mentioned what had oceured to myself as a most serious consideration, that poking a hole below the water gare a greater pomer of 
inundating tlue ship with water, than of course poking a hole abore the water or near the surface. 'libat is quite right, and I had alreads scriously taken that into consideration, or I should not hare proposed it to sou, and thercfore I merels call jour attention to that drawing, and to request you to notice that if a spear aut into the botton of that (Diagtam I) bclow the armour plate, which was his intention, it would find itself in a watertight compartment, which cither would be already filled with fucl, or if the fucl was taken out would be replaced by water ballast, and that the poling a liole into that ship at that place with his spear rould do her no liarm whaterer. And the only reason $I$ ask jou to belicre that is, that when the "Great Eistem" was speared in like manner by a rock bir cuough to tear in her a bole nine feet wide and ejghty-three fect long, it went into the compartment, and she continued her journey to Ameriea 23 if nothing had happened, aud cane back from America as if nothing had happened. I adriso my cnemics to take a spear prow, but I adrise rou as my friends to take that chisel, which chisel will open up the side of the ship, and neross sercral decks, and so not only admit water on sereral decks instead of one, but will cut up so much of the strength of the ship bs serering all these decks that you will do infinito constructire harm to the ship at the same moment that you inundate three decks with water instesd of onc. ${ }^{1}$ Thoso are my impressions. In regard to torpedo boats, I perfectly admit the good policy of England building torpedo boats, and perfectly adinit the good policy of England furnishing her flects with better torpelo boats than anybods elce has. I entirely agree that the flect shall be surrounded with crery kind of ressel. I may also say I do not underralue a ressel with a turret in it for going up a marrow winding inland channel, so that the ship maj be leceping her own course, while her gun is always Iring on the encmy on land; and $I$ do not say a rord about piroting guns or ngainst guins in turrets, becuuse there are special ecrrices for wlich. I cntrent Jou to build turret ships, because they nre better than any other, and there ure other uses for which I cntreat jou to use guns with the greatest possible sweeping power and the greatcst command orer crery direction; only I say, use them in tho discriminatine places for wbich they are manted, and do not for n thicorctical, or esceptional, or fanciful mode of application, sacrifice the great clement of a brosdside gun, namely, destroying your cnemy, when you come to close, ficree, deadly contact with him. In regard to very small gun-boats, I think there is a great difierenee betmeen what $I$ would call a squadron of gun-boats, becauso it would be my intention, if we made those one-gun boats I hare stated, to use a number of them toget ber. I think I slould send out, if an cnems were getting troublcsome, not one of those gun-boats to meet him, nor tro of then, nor three of them,-I think I slould send out twenty altogether, and sending out twenty gunboats altogether to net on the same cnems, cspceinlly if he was a big fellow, I do not think that any more monocurring power is necessary than that of a clerer captain in

1 Tho author of the paper has since reccired the following letter from a dia. tinguished naral officer:-"Dear Sir,-I was plcascd, when rcading a leading "article on jour recent lecture at the U. S. Institution, to find that you adrocate "straight stenıs for war ships. Ten years since, in an article on ship-building, "which I publislied in the Mechanics'.llagazine, I stated that for strength, sccurity, " and means of offence under any circumstunces, thes would prorc superior to all "others. In another article on the Nary, which appeared in a leading magazine "a few months since, and which excited farouruble comments from the. Times " and other sources; I again alluded to the subject. It is possible that I may again "write on the Nars, as I am not satisfied with the present trpes of war-ships. “ I3y a singular coincideuce, in another paper, which was also published in a leading "periodical, I took your riew of torpedoes. Certainls, reecnt improrements appear " to hare inade them more manarcable; but I still lowk on them as liable to be "dungerous weapons of offence, unless it be from nergligenec when $2 t$ anchor."For defence, with tho aid of clectricity, their poner will be great, and should "this country unfortunately be forced into war with Russia, the tactics will luse to "be greatly changed from what they were in $1851-5$. We then had no fear of ". such encmies, although sercral were fished up off Cronstadt and other places.

"Trusting you will crcuse my addressing you,-I am, \&c., \&c. 
a handy boat; therefore I request sou to draw a distinction where you think it neccssary; wake your little boat with a large bore gun, one that is to go in a numerous flect and attack 2 bis encuy, and put big enough shells in the guns to sink that big enemy, and do that for your general purpose; but if you want very delicate mancurring guns in gun-boats for special purposcs, by all means build them for those special purposes, and gire them special nanes which eluall indicate that they are meant for that special purpose and not for another. The one thing $I$ confess I should like to feel in a little stcamer, if I was going into an encury's countrs, would be to fecl that I had ouly first to get ucar him and then to take iny own quict time of pointing $m y$ gun at him, and to fcel that if that shell got into him be went down and all was right. Jrajor Jaylis suid torpedocs ccrtainly were a great danger. Now I cutirely agreo with that. I am rery eorry any one should think I did not imagine thes were a great danger-I hnom that they are rery ecrious dangers and ought to be looked after. But really, after all, I can say nothing to sou about torpedocs but this-Let a flect be composed of all the proper arms that ought to conpose a flect in correspondence with what Admiral Robirison so wisely said, and then let it be distinctly understood as between you and me that the great way of mecting torpedoes is this, to sink the torpedo boat first, and that there is no other way of getting rid of it. I think that is the marim we ought to keep in viewwhether you think a torpedo boat is the best thing to sink another torpedo boat, or whether you think that a very handy quick gun-boat, with a great big gun firingi nto the torpedo bont, is the best way to eint her, is a matter which I must leare entirely to your choice who hare got to go and do the deed and hare therefore the right to choose your weapons, but I mould choose the guns.

$\mathrm{Mr}$. Welsh gare us a rery interesting uecount of these Chinese gun-boats and the Argentino boats, but I merely call his attention to this, that for an English Nary I should like longer boats, I should like faster boats, and I should like boats drawing more rater, able to keep the sta, and coalcd for a tolerably long rojage. dil these little shallow-water short boats are capital things, but I entreat you to consider that though they are capital things for risers, for harbours, for local protection, for drilling men in gunnery, still you must dran a marked distinction between local epccial ecrriecs of that kind and such a fect of gun-boats as must be made to accompany our flect of large ships and assist them in their operations. Now these are totally different classes, and I think a flect, in order to bo fit for all its uses, must be composed of both, and therefore, as I said before, the swall vessels which are to protect the cmpire abroad will hare to be sent out there and be ready for the wrork there a good whilo before the big ressels are called upon. But I think it rould be a grand thing to fecl that there was $x$ great fect of our gunboats out, we will say at Sfiney or some such place, and that there were a coup!c of great ilcets out somewhere in the Pacific, and that some fine morning, when we heard that someboly or other had sent ships somewhere or other to do something we did not like, that we then had nothing to do at home but say first to the ships of the largest class of the line, "Ten of you plense get ready and go to-morrom to that place;" and that they should be accompanicd by two classcs smaller than themselres, but able to steam the snme distance; and if that flect were to leare on the instant, without anybody knowing where she was going, and go out there and find an assemblage of gunboats and good soilors in our colonics and other parts of the empire all ready, and rainting nothing to squash the enems, except our presence with theso large slips; I think people rould feel that that was an enpire of which thes had reason to be proud, and in the gorernment of which, they might place infinite confidence.

Admiral Robinson has been kind cnough to go into this matter very scriousls. IIe admits that what is wanted in a flect is that there shall be some standard ship, and eome standard unit of a gun -boat, and some standarl gun to that; cach staudard composing an integral part of a flect shall nerer be called a flect until it is surrounded by all the sereral ships which belong to a fleet. What these ships are jou can casily sum up, but thes are first of all our great ships of rar; frigates not fo hearily armed, which will accowpany them, and which will be able to deal with all the encmiez of a reaker sort than thoso with which these bare to deal; then jou hare transports and despatch ressels and cruisers, and you hare all those classes which are necesiary to form a flect. Now there are so mavy clercr mechanics and ship 
builders in England who baso no work to do, and thero is so much iron in England just now that nobody knoms what to do with, thit this srems to me a happy moment for you professional men suggesting to the country that as mo are at perfect peaco at present, nor is an admirable opportunity to unako ourzelres perfectly ready for mar against anjbody in anj part of the British cinpirc. Adminal Robinson, I think, has done us great good bs his lindness and his courage, for I am told it mants a great deal more coumge for a naral oflicer to spcal out on land than it docs to sink his cnemy at sca. I do not knor whether I am right. We want then, accordin to ddmiral Robinson, a Acet, not a ship, and we nerer sliould expect to build a ship mhich will go crerswhere and do crersthing. We build a flect of sbips for general larger purposcs, and wo build Botillas of special ships for opecial uses; that is plain practical risclom.

Captain Scott las bcen lind cnough to grasp the whole question, and ho also sajs that he took into consideration how to build, not ships, so much as a lect, in order to protect our coininerce all orer tho world. If has also backed ms masim that the way to get rid of torpedoes and other cnemies is to sink them first; and he knors, as I do, that the rocket is a ureapon; that tho slell, in ecreral shapes not generally knoss, is a serious wenpon; that these aro not to be neglected; but though they aro not to be neglected, we are not to wako them a scare to ourselres or to our friends. I agreo with Captain Scott, that if sou can get simple mechanical appliances that mon't go wrong, to help you to work your guns, to help you to steer and mancurre your ship, you will be most unwise to neglect such help, but I think you would be most unwise to trust for the fighting of jour great ships solely to tho perfect rorking conditions of tho terribly complicated apparatus of which jou and I hare heard a great deal too much. And let me eimply ear to you that the first stroke of jour bow on the enems, or of his on you, will gire a little trist to this bulkliead, and a little twist to that bulkliead, and will pole up 2 little bit of iron of the ship this way, and buekle down another bit of iron in the ship that ras, and I will tell you that wine-tenths of tho liorriblo complications of machinery which $T$ hare secn proposed, not to 825 esecuted, for sour mar ships rill be utterly uscless on the first slight contact with your cncur. Though I am an enginecr, though I beliere in machinery, I adriso you not to belicre in clercr tricls of mechanism that $I$ or ansbody clse teach you, and be surc of this, first, mako jour rudder and your stecring gear and ererything belonging to it to that jour eren can steer withont anj cngino or machinery; secondly, hare jour gung so arranged that thes can be worhed without a stcans. engine being in good order, or the bydrant press being in perfect condition, or without all tho lines of the mechanism being vnathematically true, - take care that rou can work with your orm crow jour omn guns. And if you ast me the redson irhy more strongly than any other I lay such weight on haring a brecelh-loading frun instead of a great mlizzle-loading gun worked by steam-engines, I tell jou Why, because I hare seen big brcch.loxeling guas handled by tro or three littlo fellows morking at the brecels of the gun in such an exquisite and rapid manner as no machinery of hydratics or steam in the rorld could accomplish. But in order to do that it must be brech-loading, and a handy littlo breech-loading gun fineen iuches in disweter will bo rorked by half-a-dozen Jack tars, and say in half the time that ans of your great guus can be rrorkecl. Therefore I entreat you to keep to the simplicity of all the mechauism on board a ship, to kecp in reserre, to be land, some rery simple mechanism which, when you aro rery tircl of firing so many guns at jour enems, will como in and gire jou a little relicf. In the ships $I$ haro shown $I$ haro divided the meight pretty nearly thus:-I hare dirided is nearly as possiblo the 4,000 tons' reight of nmament, taking 2,000 tons' weight of guns and ammunition and 2,000 tons' weight of armour, snd I rompelled nigself to make the best $I$ could of that; and I hare done so by the arrangenient $I$ hare now shown jou. By going a littlo further I could hare 3,000 tons of armour and a corresponding increase in tho guns. I think that is of great importance, because you sec there will be a far more porrerful armament in that ship I have shown you, in reg.urd to her neight of :trmour and the reight of tho slip nllogether, thith ansthing sou hare see been finiliar with. Therefore with regard to guns, I think, that for this close fighting, 
Which must be the accompaniment of ramming, a big bore light gun and a large shell with a high initial velocity, is something you ought on no account to deriate from. I hare no knomledge of fring by electricity, but if jou ask me how I meant to fre from these casemates, I will answer you. I intended that at each ensemate there should be a small liatehway opening up on the uprer deck. In eacls of these jou hare loaded your gun, arid in each there is a gunner standing below ready on the slightest hint to fire his gun. IIc is standing there at his work, and the commander is standing alung this line and sces all the captaius of the guns who arc looking out at him for the signal. I fancy ho is standing her, and they are all ready, on the instant of his giving the signal, to fire each his omn gun. If you do not aplrore of that, you no doubt will prore a better was of doing it. 'There is a way which is very well known, namely, fring by electricity. I do not know, onls, I say again, use electricity for what it is fit for, but do not trust to it, and do erergthing with your own men as much as jou possibly can.

With regard to the shot being broken by double layers of plate, I quite agree there are rery serions points of that bind coming up now. I haro the whole side of the ship along that battery three fect thick for strength (sce Diagrams I and ID), independent altogether of armour, and therefore that thrce fect thick encloses erers one of those large armour plates as it were in a casc, and whether you diride that into tro or three- whether you fill up tho interral by rood or not, do it which mas you like, but there is no doubt whaterer that you can in this manner combine the strength of the armour plate with the strength of the matcrials of the ship. But there was ono very excellent criticism giren, which was this : it was said, "If the plate of jour ship is as jou sas outside the shect of armour, then, when the shell comes, the first thing it will do will bo to damage that part of the skin of the ship." That is just what I wanted it to do. I ranted it to go through and damage that part of the ehip, and hammer that iron, which it does, into a littlo bucklo; but haring done that, it has done no harm whaterer to the ship or the etrength of the ship; it has altered none of the fastenings, because no support is derired to tho plate from that part of the plate : all tho support to the particular armour plate is derived from those buttresses along with those bnces which I spoke of, and I said to you that erery one of those outer plates of the shin could be battered by half-a-dozen shells, and the cells inside would all remain perfectly water-tight, and no barm rould hare happered, and it rould still form an enclosure which would grasp the iron plates all round, and so present the portions of it, even if it las been split, from tumbling and falling awray, and would kecp crers one of them in their places, so that as long as there was material to be broken, the material would be there and would require forco to break it.

I think it most important that the propeller should protect itself. I cannot go into that method now, but I wish you would hare a paper read here by other people on that subject, and if you would just say that what you want is a propellcr capable of protecting itself, I think I could show you how a propeller may be made not only to protect itsclf, but to make its cnemy rery uncounfortable. The propelles I do not think is to be made to protect itself by putting any nets around it. I disapprore of all such complications; but $I$ will only tell you $I$ bare seen a kind of propeller, and used it for practical purposes, which no ordinary and eren no estraerdinary process which I can understand would render useless, and I think that is well worthy the consideration of this mecting, and I shall be ready on such an occasion to gire you suclı a propeller if no one elsc docs.

Then another point with regard to propellers, $I$ think most eerious, it is this, that jour screw propeller is a bad propeller sternwards. Why not say, "A ship of war must be able to go as fast astern as ahead?" Why not sas eo? And then when jou hare said so, why not call upon people who hare made such things their studics to put it into cxccution? I assure you, handling a ship as I hare bad to do, which gocs forward and backmard cqually $\pi \mathrm{ell}$, is onc of the greatest pleasures in life, and jou can make such a ship do anything you like. Such resscls hare been made, only at present we are in a rery scrious difficulty, we are in a sort of curious entanglement about serers. I do not know if you hare scen our doublo screw war vesscls. I dare say jou hare ecen them with great big beams sticking out through the mater in the most unmechanical manner to grasp the screr. I an sure an old ship-builder nerer 
would construct a ressel with big benes going through the water in order to grapple a distant propller and kecp it in its place. It rould, I am certain, bo casils cntangled by cables, cr injured e:sily in collision by clerer cnemies, nud I cut reat you to get rid of such an arrangenent, for it is an abomination and a danger. I will ouly, in conclusion, repeat the old maxim that "ships good for crerything are good for nothing," and apologise for taking up so nuch of your time.

Tho Cenarisas: $\mathbf{I}$ am sure, after this lengthened lecture and debate, there can be rery little doubt of 3 Ir. Scott Russell's clererness, and his ability to instruct ua. We aro rers much indebted to him, not only for the amusenent he lins afforded us, but for the gool solid instruction we hase gained, and I am sure the meeting will join with me in thanking him rery much. 